\title{
A lysimeter study under field conditions of nitrogen and phosphorus leaching in a turf grass crop amended with peat and hydrogel
}

\author{
M.A. Martin del Campo a , M.V. Esteller ${ }^{\text {a,* }}$, I. Morell ${ }^{\text {b }}$, J.L. Expósito a , G.L. Bandenay ${ }^{\text {c }}$, C. Díaz-Delgado ${ }^{\text {a }}$ \\ ${ }^{a}$ Centro Interamericano de Recursos del Agua (CIRA), Facultad de Ingeniería, Universidad Autónoma del Estado de México, Cerro Coatepec s/n, C.U., 50130 Toluca, Mexico \\ b Instituto Universitario de Plaguicidas y Aguas, Universitat Jaume I, Av. Sos Baynat s/n, 12071 Castelló de la Plana, Spain \\ ${ }^{c}$ Universidad de Ingeniería y Tecnología. UTEC. Jr. Medrano Silva 165, Barranco, Lima, Peru
}

\section{H I G H L I G H T S}

- Hydrogel amendment reduces $\mathrm{N}$ and $\mathrm{P}$ leaching as well as water percolation.

- Peat amendment does not impact the percentage of leached $\mathrm{N}$.

- The largest amount of $\mathrm{N}$ and $\mathrm{P}$ leached is detected in the plot no amendment.

- A larger irrigation rate ( $>10 \mathrm{~mm}$ ) favors leaching of $\mathrm{N}$ and $\mathrm{P}$, and water percolation.

\section{A R T I C L E I N F O}

\section{Article history:}

Received 16 May 2018

Received in revised form 14 July 2018

Accepted 11 August 2018

Available online 12 August 2018

Editor: José Virgílio Cruz

\section{Keywords:}

Nitrogen

Phosphorus

Leaching

Hydrogel

Grass

\section{G R A P H I C A L A B S T R A C T}

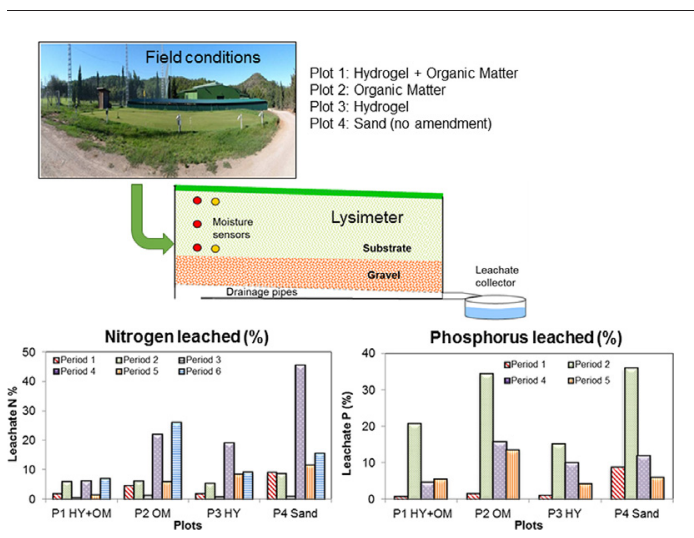

\begin{abstract}
A B S T R A C T
Golf courses represent an agricultural activity wherein grass is intensively cultivated using large quantities of fertilizers. In the present study, nitrogen and phosphorus leaching was analyzed over two years in an experimental green under actual field conditions. The green contained four plots with distinct amendments (P1: hydrogel + peat, P2: peat, P3: hydrogel, and P4: no amendment). The applied doses of nitrogen ranged from 5 to $103 \mathrm{~kg} / \mathrm{ha}$ and of phosphorus from 9 to $31 \mathrm{~kg} / \mathrm{ha}$. The irrigation level varied as a function of the rainfall regime and the water requirements of grass; overall water intake varied from 1550 to $2080 \mathrm{~mm} / \mathrm{year}$. Daily, leached water volume was calculated, and samples were taken for chemical analysis. Nitrogen and phosphorus mass balances were calculated for different periods based on the collected data.

The plot amended with peat and hydrogel (P1) had reduced water flow; the percentage of drainage water varied from 8.4 to $29 \%$. As a result, the dissolution and leaching of nitrogen $(\mathrm{N})$ and phosphorus $(\mathrm{P})$ were the lowest in comparison to the other plots. According to the calculated mass balances, the lowest leaching values were also recorded in this plot (P1), ranging from 0.5 to $6.3 \%$ for $\mathrm{N}$ and from 0.8 to $20.9 \%$ for $\mathrm{P}$. The plot without amendment (P4) drained the most water (25.9-44.8\%) and leached the highest quantities of $\mathrm{N}$ and $\mathrm{P}$, ranging from 9.1-45.7\%, and $6-35.9 \%$, respectively. The use of double amendments (hydrogel and peat) therefore represented optimal operating conditions for the green. Moreover, a relationship was found between increasing rates of fertilization and increasing percentages of $\mathrm{N}$ and $\mathrm{P}$ leaching as well as between higher irrigation levels and greater leaching.
\end{abstract}

(c) 2018 Elsevier B.V. All rights reserved.

\footnotetext{
* Corresponding author.

E-mail address: mvestellera@uaemex.mx (M.V. Esteller).
} 


\section{Introduction}

The installation and maintenance of golf courses constitute a demanding agricultural activity involving the intensive cultivation of large areas of cespitose plants that require quantities of water similar to those required by citric crops, sunflower, and rice (Morell, 2006; Shuman, 2006). As demand for water in golf courses is extremely high, drainage also represents a key variable to consider because substrates are porous. In addition, large quantities of agrochemicals (fertilizers and pesticides) are used. The high solubility and excessive application of these products, as well as inefficient management practices, lead to the transport of their contained compounds to deep soil layers. These compounds may then reach aquifers or discharge to surface water bodies through run-off (Siyal et al., 2012; Krčmář et al., 2014; Filipović et al., 2015). The maximum permissible limits of such compounds established to protect the quality of water resources, including both drinking water and aquatic life, are commonly exceeded (Wong et al., 1998; Shuman, 2001, 2003; King et al., 2012).

The rate and system of irrigation, the quantity and type of applied fertilizers, and the frequency of fertilization, additionally affect the leaching of contaminants (McLeod et al., 2001; Shuman, 2001, 2003, 2005, 2006; Krčmář et al., 2014). Studies of agrochemical leaching in golf courses have been based on the use of lysimeters or have been carried out in greenhouses (Wong et al., 1998; Shuman, 2001, 2003; Aamlid et al., 2009), yet few studies have been carried out under actual field conditions.

Wong et al. (1998), for example, simulated irrigation and fertilization conditions characteristic of a golf course using a lysimeter to evaluate the behavior of fertilizers. According to the results, the rate of application of fertilizers in greens leads to adverse environmental impacts on surface water and groundwater because of phosphate and nitrate release. Shuman $(2001,2003)$ evaluated nitrate and phosphate leaching in golf courses using columns constructed according to the specifications of the United States Golf Association (USGA). The application of fertilizers was controlled considering soluble compounds and controlled-release compounds. The results showed that phosphate leaching is a potential problem only following an excessive increase in the application rate of soluble compounds. However, nitrate is a continual problem because it is easily leached.

In this respect, King et al. (2012) studied different types of fertilizer and application methods in a golf course in Duluth, USA. These authors found that the application of controlled concentrations of organic fertilizers during certain periods decreased the quantity of reactive dissolved phosphorus and total phosphorus in contrast to traditional techniques using synthetic fertilizers. In another study carried out in a golf course in Idaho, USA, under normal operating conditions (Johnston and Golob, 2002), the state of the grass was found to determine whether groundwater was contaminated as a result of nitrate leaching. Specifically, leaching was reduced when grass was maintained in good conditions.

Overall, several research studies in golf courses have concluded that it is necessary to improve irrigation techniques and fertilizer application (Barton and Colmer, 2006; Filipović et al., 2015) to guarantee the maximum use of fertilizers by plants and to avoid contamination problems. One improvement technique is the use of compounds such as peat, hydrogels, or surfactants to increase the efficiency of water and agrochemical use (Aamlid et al., 2009; Ullah et al., 2015). Hydrogels are superabsorbent hydrophilic polymers that are added to the soil to improve porosity, aeration (oxygenation), infiltration, transport and liberation of nutrients, and water absorption; these factors subsequently improve plant growth (Akhter et al., 2004; Abedi-Koupai et al., 2008; Anna et al., 2011; Bai et al., 2013; Savi et al., 2014; Ramos-Campos et al., 2015). In addition, a couple of studies have reported that hydrogels can control fertilizer leaching (McAvoy, 1994; Ullah et al., 2015).

Based on the abovementioned context, the objective of the present study was to evaluate and analyze nitrogen and phosphorus leaching in an experimental green simulating a golf course under actual conditions. Distinct irrigation levels and amendments (peat and hydrogel) were considered. Nitrogen and phosphorus mass balance were calculated to establish the optimal operating conditions that would avoid contaminating ground water or receiving water bodies.

\section{Study area}

An experimental green with an approximate area of $278 \mathrm{~m}^{2}$ is located at the Club de Campo del Mediterráneo along the Mediterranean coast of Spain (Fig. 1). It contains four experimental plots of approximately $40 \mathrm{~m}^{2}$.

The substrate is composed of a $26-40 \mathrm{~cm}$ sandy baseoverlaying a $10-$ $\mathrm{cm}$ gravel layer containing drainage pipes that collect leached compounds and drain them toward the exit. At the exit, recipients collect leachates for control purposes. Each plot is coated on the bottom and sides with a geomembrane that independently collects and channels all infiltrated water toward the drainage exit (Fig. 1).

Each plot has a construction design and is composed of distinct substrates, which are described in Table 1. One plot (P2) was constructed according to USGA requirements (USGA, 2004) specifying that greens contain sand and organic matter in an 80:20 ratio. The other construction designs were proposed to evaluate their influence on drainage and contaminant transport. Several of the plots contain peat (organic matter) and TerraCottem ${ }^{\circledR}$ (hydrogel). TerraCottem ${ }^{\circledR}$ is an additive formed from a mixture of different acrylamide and acrylic acid copolymers, fertilizers, and volcanic rock and absorbs water up to 45 its weight, so it is capable of forming water reserves in the soil. These compounds are used to improve the efficiency of water and nutrient use and to therefore improve grass quality and decrease the risk of contaminating receiving surface water bodies and groundwater.

The experimental green was equipped with a Rain Bird Smart Weather meteorological station that recorded data on rainfall, solar radiation, maximum and minimum temperature, wind velocity, and relative moisture. From these data, reference evapotranspiration $\left(\mathrm{ET}_{\mathrm{o}}\right)$ was calculated using the FAO-Pennman-Monteith equation (Smith et al., 1992; Allen et al., 1998).

Organic matter content, bulk density, porosity, field capacity, and infiltration rate are shown for each plot in Table 1. Amendments affect field capacity and infiltration and, therefore, possibly influence contaminant leaching. The most remarkable difference between the plots is that the P4 (100\% sand) has the highest infiltration rate, whereas the plots containing organic matter ( $\mathrm{P} 1$ and $\mathrm{P} 2$ ) have the lowest infiltration rate. The USGA (2004) recommends a minimum infiltration rate of $0.25 \mathrm{~cm} / \mathrm{min}$ in new greens. However, Gaussoin (2012) highlighted that, in the first three years, the infiltration rate of greens is between approximately 0.46 and $1.33 \mathrm{~cm} / \mathrm{min}$.

Agronomic activities performed in the plots are described next:

a) Planting: Agrostis stolonifera L-93 was selected for planting. This grass variety is green throughout the year and is used by Club de Campo del Mediterráneo. It requires a high level of maintenance because of its rapid growth during summer and its high water requirement. It is sensitive to stress from lack of water and shade and endures cuttings of up to $3 \mathrm{~mm}$.

b) Irrigation: irrigation water originates from a well located in the vicinity. Eight pop-up spray sprinklers (model 6406-ADV, Nelson Turf®) were installed at a height of $15 \mathrm{~cm}$ with 7370 Multi-Arc nozzles at an optimal working pressure of 2 bar. The sprinklers were located around the perimeter and each separated by $4 \mathrm{~m}$. The irrigation systems are independent in each plot and controlled by an electric pump and meter, allowing distinct irrigation doses to be quantified and tested.

c) Fertilization: diverse types of fertilizers were applied uniformly to all plots, as described in Table 2. The periods and types of fertilization were congruent with the agricultural practices of the golf course. 

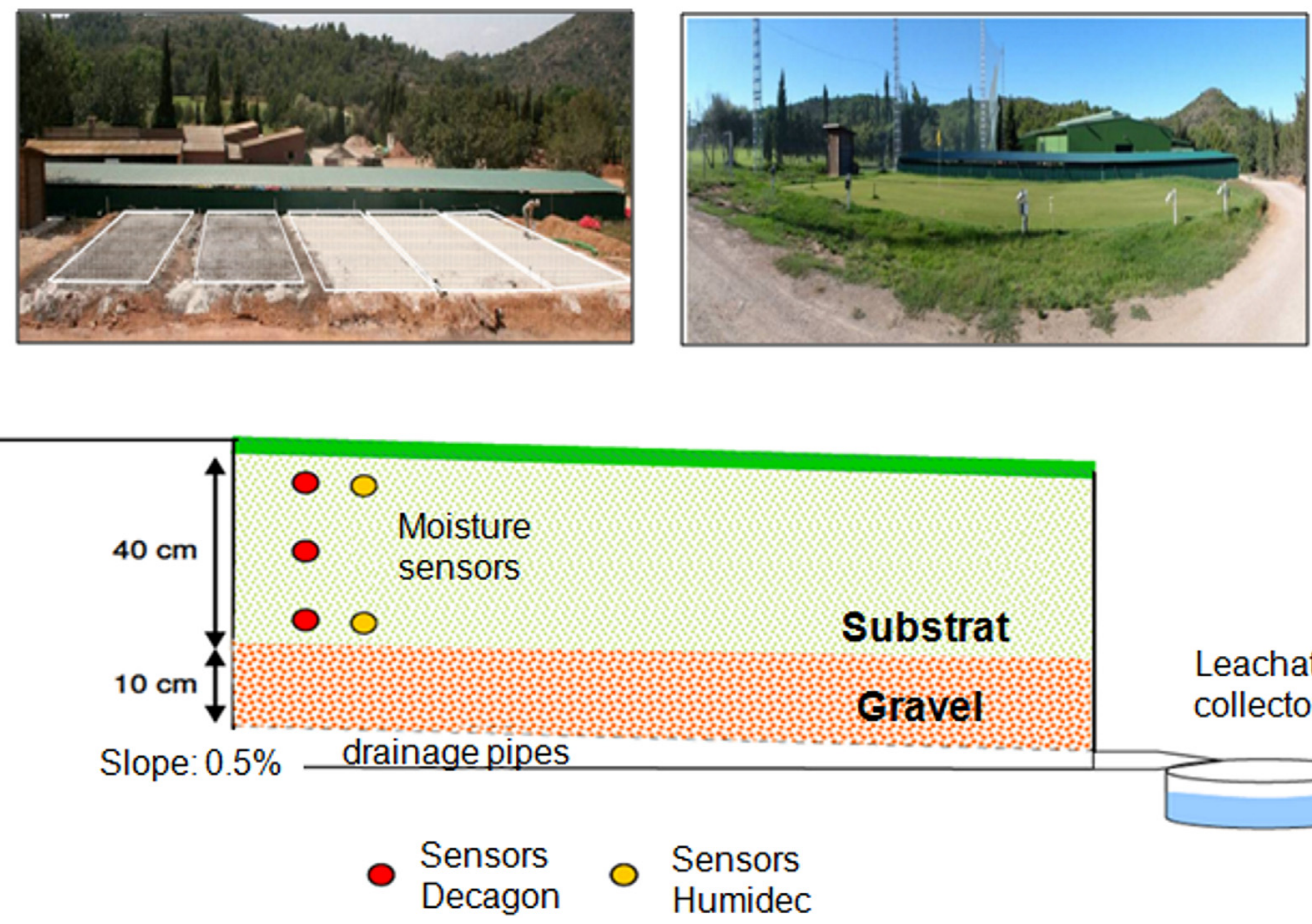

Fig. 1. Location of plots in the experimental green and construction scheme.

Additional activities carried out in the green included frequent mowing and aeration, or punching, which consists of punching holes to avoid compaction, improve root aeration, enhance water penetration, and facilitate posterior reseeding in addition to verticut, which is a process of vertical mowing to maintain grass density, eliminate weeds and dead stems, and remove thatch.

\section{Materials and methods}

The green was established and planted in August 2008. Activities were continued on the green until December 2011.

\subsection{Water balance}

In systems uninfluenced by water flow from neighboring systems, the main inputs are rainfall and irrigation, and the outputs are drainage and water loss due to evaporation and/or transpiration of plant cover. The difference between input and output constitutes the variation in water storage (moisture).

Irrigation input volume was quantified based on data obtained from meters connected to the irrigation system. Water quantity in each plot was determined based on the assumption that irrigation is uniform.

Rainfall and $\mathrm{ET}_{\mathrm{o}}$ (reference evapotranspiration) were quantified using data from the installed meteorological station. Leachate volume was measured daily in recipients installed for this purpose. EVT (evapotranspiration) was calculated from the water balance based on input and output water volumes in each plot.

\subsection{Mass balance}

Water samples were collected daily in the leachate collectors of each plot. Sample collection, preservation, storage and transport to laboratory were in conformity with the guidelines specified by APHAAWWA-WFPC (2005). Each sample was collected in a $200 \mathrm{~mL}$ plastic container, which was appropriately washed in the laboratory. All samples were stored under refrigeration $\left(4^{\circ} \mathrm{C}\right)$ until analysis. Water samples were analyzed in the laboratory of the Institute of Pesticides and Water of the Jaume I University, Spain. Nitrate $\left(\mathrm{NO}_{3}^{-}\right)$and ammonium $\left(\mathrm{NH}_{4}^{+}\right)$were determined by UV-Visible spectrophotometry (Shimadzu UV-1603). Phosphate $\left(\mathrm{PO}_{4}^{-3}\right)$ was analyzed by ionic chromatography (Dionex DX-120). Several field parameters were measured in situ, including $\mathrm{pH}$, water temperature, and electrical conductivity, using an Orion 5-Star Plus multiparameter.

The study periods for which nitrogen and phosphorus mass balances were estimated, were defined considering the following criteria:

i) The agricultural practices carried out by the maintenance staff of the golf course, which is based on maintaining the grass with the appropriate characteristics (visual quality of grass).

Table 1

Construction characteristics and physical characteristics of each plot (P2 complies with USGA standards) (Bandenay, 2013).

\begin{tabular}{|c|c|c|c|c|c|c|c|c|}
\hline Plot & Area $\left(\mathrm{m}^{2}\right)$ & Volume $\left(\mathrm{m}^{3}\right)$ & Composition & Organic matter (\% weight) & Bulk density $\left(\mathrm{g} / \mathrm{cm}^{3}\right)$ & Porosity (\%) & Field capacity (\%) & Infiltration rate $(\mathrm{cm} / \mathrm{min})$ \\
\hline P1 & 37.5 & 10.5 & $\begin{array}{l}80 \% \text { silica sand } \\
20 \% \text { white peat } \\
145 \mathrm{~g} / \mathrm{m}^{2} \text { hydrogel }\end{array}$ & 4.045 & 1.467 & 40.14 & 34.56 & 0.69 \\
\hline P2 & 37.6 & 11.2 & $\begin{array}{l}80 \% \text { silica sand } \\
20 \% \text { white peat }\end{array}$ & 7.397 & 1.394 & 51.65 & 45.83 & 1.26 \\
\hline P3 & 36.5 & 10.6 & $\begin{array}{l}100 \% \text { silica sand } \\
145 \mathrm{~g} / \mathrm{m}^{2} \text { hydrogel }\end{array}$ & 0.178 & 1.784 & 34.41 & 28.47 & 2.85 \\
\hline P4 & 35.4 & 9.3 & $100 \%$ silica sand & 0.139 & 1.684 & 34.88 & 26.75 & 3.38 \\
\hline
\end{tabular}


ii) Fertilization dates. The date on which the fertilizer is applied (Table 2) was taken as the start date of the study periods. This application date was defined by the maintenance staff.

iii) The evolution of the concentration of the ions in the leachate. The end date of the study period was identified considering when the concentration of the ions in the leachate was stabilized. This value could be considered as a baseline value (minimum concentration), which would represent the end of the process of leachate that had started at the date the fertilizer was applied.

Additionally, the available data were reviewed to verify his continuity in the database (values of drainage water volumes and ion concentrations daily) throughout the study periods.

Based on these criteria, six study periods were defined (Table 2).

a) Nitrogen

The nitrogen mass balances of each plot were calculated to evaluate nitrogen losses (Shuman, 2001, 2003, 2006; Barton and Colmer, 2006) and to assess the possible influence of the different construction designs.

Nitrogen inputs originate from fertilization, irrigation, and, to a lesser extent, rainfall. The quantity of nitrogen contributed by fertilizers depends on the quantity used and the type of fertilizer (Table 2).

Nitrate mass in irrigation water was calculated by summing the quantity of water inputted to the green daily for each defined period, which was then multiplied by the average $\mathrm{NO}_{3}^{-}$concentration in irrigation water $(20.14 \mathrm{mg} / \mathrm{L})$ and divided by $1000 \mathrm{~g} / \mathrm{mg}$ to obtain the mass (g). To obtain total nitrogen mass contributed by irrigation, the obtained $\mathrm{NO}_{3}^{-}$concentration was multiplied by the atomic weight (in $\mathrm{g}$ ) of nitrogen $(14.01 \mathrm{~g} / \mathrm{mol})$ and divided by the molecular weight of $\mathrm{NO}_{3}^{-}$ $(62.01 \mathrm{~g} / \mathrm{mol})$.

The quantity of nitrogen contributed by rainfall to the system was determined by rainfall level and $\mathrm{NO}_{3}^{-}$concentration. To obtain the value of nitrogen contributed by rainfall to the experimental green, the same procedure for calculating the nitrogen contribution of irrigation water was used. The average $\mathrm{NO}_{3}^{-}$content of rainfall is $4.7 \mathrm{mg} / \mathrm{L}$.

The quantity of nitrogen contributed by fertilizer was determined by summing the concentrations of species of ammoniacal nitrogen $\left(\mathrm{NH}_{4}^{+}\right)$, urea nitrogen $\left(\mathrm{CON}_{2} \mathrm{H}_{4}\right)$, and isobutylidenediurea $\left(\mathrm{C}_{6} \mathrm{H}_{14} \mathrm{~N}_{4} \mathrm{O}_{2}\right)$.

To estimate nitrogen outputs, leachates were collected daily in each plot and analyzed, and $\mathrm{NH}_{4}^{+}$and $\mathrm{NO}_{3}^{-}(\mathrm{mg} / \mathrm{L})$ concentrations were determined. The $\mathrm{NO}_{2}^{-}$concentration was minimal (below the quantification limit) and was therefore not considered in the balance. The daily concentrations for each defined period were summed. Similar to the method for calculating the nitrogen contribution of irrigation water, the obtained $\mathrm{NH}_{4}^{+}$and $\mathrm{NO}_{3}^{-}$values were transformed to nitrogen.
Final nitrogen balance was calculated from the following relationship: Input nitrogen minus output nitrogen. The result was the variation in storage, which is the sum of nitrogen absorbed by roots and nitrogen stored in the substrate. Nitrogen inputs from atmospheric fixation are assumed to be compensated by nitrogen losses due to volatilization.

b) Phosphorus

Phosphorus mass balance was calculated similar to the process described for calculating nitrogen mass balance. However, several factors that influence phosphorus balance estimates were considered.

Fertilization is the only contributor of phosphorus to the plots. Phosphorus quantity was determined based on fertilizer type and quantity used (Table 2). Phosphorus inputs from fertilization occur in the form of $\mathrm{P}_{2} \mathrm{O}_{5}$, from which total phosphorus was obtained.

Phosphorus outputs in the leachates collected in each plot were analyzed in the laboratory and reported in form of $\mathrm{PO}_{4}^{3-}$. The $\mathrm{PO}_{4}^{-3}$ values were multiplied by the atomic weight $(\mathrm{g})$ of phosphorus $(30.97 \mathrm{~g} / \mathrm{mol})$ and divided by the molecular weight of $\mathrm{PO}_{4}^{-3}(94.97 \mathrm{~g} / \mathrm{mol})$.

The final balance was obtained considering the differences between input and output phosphorus, which result in the variation in storage.

During the entire study period (August 2008-December 2011), input and output water data were recorded. Water samples were collected daily from September 2008 to October 2010 (25 months).

To establish significant differences in average values of leached nitrogen and phosphorus between plots given different fertilizer doses and types, a comparison of the averages was performed using twoway analyses of variance (ANOVA) and Fisher pairwise comparison tests at a significance level of $P<0.05$ (Kanji, 1999). The statistical analyses were carried out in MINITAB software V.17.

\section{Results and discussion}

\subsection{Water balance}

From August 26, 2008 to December 31, 2011, the experimental green received 251 rainfall events and between 602 and 625 irrigations. During 2009, the irrigation guidelines were designed to complement rainfall and to satisfy the water requirements of the system. From March to December 2009, the $\mathrm{ET}_{\mathrm{o}}$ was $936.9 \mathrm{~mm}$. During 2010, the objective of the irrigation regime was to maintain the visual quality of grass, therefore a high level of moisture was maintained; the $\mathrm{ET}_{\mathrm{o}}$ for January to December 2010 was $1009.2 \mathrm{~mm}$.

According to the water balance analysis (Table 3), drainage in plots amended with organic matter (P1 and P2) increased as the level of irrigation increased. In the sandy plot (P4), the drainage percentage was generally similar regardless of irrigation level. In comparing the plots, P1 drained 42\% less water than P2, and P3 drained 32\% less water

Table 2

Fertilization periods and doses ( $\mathrm{Na}$; No application). Periods used to calculate nitrogen and phosphorus mass balances are shown in bold.

\begin{tabular}{|c|c|c|c|}
\hline Fertilization date & Fertilizer & Nitrogen (kg/ha) & Phosphorus (kg/ha) \\
\hline December 2008 & Fertilizer $15-15-15$ & 52.63 & 22.95 \\
\hline January 2009 & Proquimed $21-0-60$ (solution of $12.5 \mathrm{~kg}$ in $600 \mathrm{~L}$ of water) & $0.07-0.11$ & $\mathrm{Na}$ \\
\hline February 2009 & Physiostart 8-28-0 & 14.01 & 21.38 \\
\hline March 2009 & Physiostart 8-28-0 & 23.70 & 36.18 \\
\hline April 2009 & Easygreen $21-5-10$ & 62.01 & 6.44 \\
\hline May 2009 (Period 1) & Floranid Eagle Start 18-24-0 & 53.34 & 31.01 \\
\hline July 2009 (Period 2) & Floranid Eagle 24-5-10 & 103.72 & 9.42 \\
\hline October 2009 (Period 3) & Ammonium sulphate 21-0-0 24S & 18.91 & $\mathrm{Na}$ \\
\hline November 2009 (Period 4) & Fertilizer $15-15-15$ & 72.58 & 31.65 \\
\hline March 2010 (Period 5) & Floranid Eagle 24-5-10 & 127.83 & 11.61 \\
\hline May 2010 (Period 6) & Ammonium sulphate 21-0-0 24S & 5.25 & $\mathrm{Na}$ \\
\hline July 2010 & Floranid Eagle 24-5-10 & 52.24 & 4.75 \\
\hline November 2010 & Floranid Eagle 12-6-24 & 43.56 & 9.50 \\
\hline April 2011 & Floranid Master 19-5-10 & 68.42 & 7.86 \\
\hline
\end{tabular}


Table 3

Water balance $(\mathrm{mm})$ at the plots (HY: hydrogel, OM: organic matter).

\begin{tabular}{llllll}
\hline \multirow{2}{*}{ Year } & $\begin{array}{l}\text { Components of water } \\
\text { balance }\end{array}$ & Plots & & & \\
\cline { 3 - 6 } & & $\begin{array}{l}\text { P1 }(\mathrm{HY}+ \\
\text { OM) }\end{array}$ & $\begin{array}{l}\text { P2 } \\
(\mathrm{OM})\end{array}$ & $\begin{array}{l}\text { P3 } \\
(\mathrm{HY})\end{array}$ & $\begin{array}{l}\text { P4 } \\
\text { (sand) }\end{array}$ \\
\hline \multirow{2}{*}{2009} & Irrigation $(\mathrm{mm})$ & 993.3 & 988.1 & 1012.2 & 1057.1 \\
& Rainfall $(\mathrm{mm})$ & 584.4 & 584.4 & 584.4 & 584.4 \\
& Inflow (mm) & 1577.7 & 1572.5 & 1596.6 & 1641.5 \\
& Drainage (mm) & 374.1 & 521.4 & 386.6 & 581.1 \\
& \% (Inflow-Outflow) & 23.7 & 33.2 & 24.2 & 35.4 \\
& Irrigation (mm) & 1235.1 & 1577.0 & 1664.2 & 1496.2 \\
& Rainfall (mm) & 417.3 & 417.3 & 417.3 & 417.3 \\
& Inflow (mm) & 1652.4 & 1994.3 & 2081.5 & 1913.5 \\
& Drainage (mm) & 380.2 & 795.4 & 479.1 & 634.9 \\
& \% (Inflow-Outflow) & 23.0 & 39.9 & 23.0 & 33.2 \\
\hline
\end{tabular}

than P4. Water retention was greater in $\mathrm{P} 2$, which was amended with organic matter, with respect to the $100 \%$ sand plot (P4). However, water retention was even greater in the plots containing hydrogel (P1 and P3), which is consistent with the properties of this material (Akhter et al., 2004; Abedi-Koupai et al., 2008).

\subsection{Nitrogen mass balance}

To calculate nitrogen $(\mathrm{N})$ mass balance, the planting and establishment periods of grass, which occurred between August 2008 and May 2009, are important to consider. During this time, the $\mathrm{NO}_{3}^{-}$concentration in leachates was greater than that recorded during later months (although this information was not considered in the present study). Greater leaching during the planting period has been confirmed by other researchers (Johnston and Golob, 2002; Barton and Colmer, 2006) and has been attributed to the higher rate of soil mineralization and the incapacity of grass to use mineralized $\mathrm{N}$.

Hydrogel and organic matter (P1) jointly act to retain water and to hinder $\mathrm{NO}_{3}^{-}$leaching, as shown in Table 4 and Fig. 2a. Despite reaching a maximum value of $82.5 \mathrm{mg} / \mathrm{L}$, the $\mathrm{NO}_{3}^{-}$concentration of drainage water was the lowest in P1 compared to the other plots. Also, the average leached $\mathrm{NO}_{3}^{-}$concentration was $19.8 \mathrm{mg} / \mathrm{L}$, nearly half of the average concentrations recorded in the other plots.

In the plot without hydrogel (P2) that was amended with peat according to USGA specifications (Fig. 2b), the water flow was not retained as much as in P1. Therefore, a greater percentage of water was drained (Table 4). The $\mathrm{NO}_{3}^{-}$concentration in drainage water was also higher, with a maximum value of $141.3 \mathrm{mg} / \mathrm{L}$ and an average value of $27.5 \mathrm{mg} / \mathrm{L}$ (Table 4). A relationship between water input volume, fertilization days, and maximum $\mathrm{NO}_{3}^{-}$leaching was observed in P2. After fertilization and water inputs above $20 \mathrm{~mm}$, an increase in leachates was recorded. The response time was short, which may be due to the existence of preferential flows (Fig. 2b). Another notable finding is the continuous contribution of $\mathrm{NO}_{3}^{-}$. Even after fertilizations, $\mathrm{NO}_{3}^{-}$concentrations above the average value $(27 \mathrm{mg} / \mathrm{L}$ ) were recorded, which may be due to the slow liberation of $\mathrm{N}$ from fertilizer.

In P3, water flow was modified and retained at the surface because of the action of the hydrogel. This was also reflected in the percentage of drainage water, which was similar to P1 (Table 4). However, in contrast with P3, a maximum $\mathrm{NO}_{3}^{-}$concentration of $200 \mathrm{mg} / \mathrm{L}$ was reached on three times (May and December 2009 and March 2010) (Fig. 2c); these values were higher than those reported in P1 and P2 (Table 4).

The maximum $\mathrm{NO}_{3}^{-}$concentrations in $\mathrm{P} 4$ exceeded $250 \mathrm{mg} / \mathrm{L}$ at several times (November and May 2009 and March 2010). In addition, a baseline $\mathrm{NO}_{3}^{-}$value was observed, with an average concentration of $20 \mathrm{mg} / \mathrm{L}$ (Fig. 2d).

Notably, in the plots with amendments (P1, P2, and P3), $\mathrm{NO}_{3}^{-}$concentrations were lower than those in the plot composed of only sand (P4), demonstrating the effect of amendments on the leaching process. However, water inputs and flow within the system should be considered because these can produce an increase in drainage water volume, which may promote $\mathrm{N}$ leaching.

The temporal evolution of the quantity of leached $\mathrm{N}$ and the $\mathrm{N}$ mass balance were studied in detail according to the study periods defined (Tables 2 and 5).

a) Temporal evolution of leached nitrate per fertilization period

For each of the study periods, an analysis of the temporal evolution of the concentration of $\mathrm{NO}_{3}^{-}$was made in each of the plots. This analysis allowed to verify that there is a certain similarity between periods and plots. For example, for periods 1 and 2, the maximum $\mathrm{NO}_{3}^{-}$concentration was detected in $\mathrm{P} 4$ and occurred between 3 and 5 days after the application of fertilizers. Once this maximum concentration was reached, a gradual decrease was observed; reaching values lower than $15 \mathrm{mg} / \mathrm{L}$ (Table 5). P1, P2 and P3 presented relatively a uniform behavior with small peaks in $\mathrm{NO}_{3}^{-}$concentration.

The third and sixth periods were the shortest (Table 5) and the same fertilizer was applied (Table 2). The plots have a uniform behavior with slight variations in $\mathrm{NO}_{3}^{-}$concentrations, which did not exceed $30 \mathrm{mg} / \mathrm{L}$ (Fig. 2). In contrast to the two prior study periods, in P4 (100\% sand), slight fertilizer leaching was observed. $\mathrm{NO}_{3}^{-}$leaching was delayed in the plots amended with hydrogel (P1 and P3), as leaching occurred 20 days after fertilization.

The fourth and fifth periods are the longest (Table 5). Leaching was observed in all plots immediately after fertilization. In $\mathrm{P} 4$, the $\mathrm{NO}_{3}^{-}$concentrations reached a maximum of 385 and $266 \mathrm{mg} / \mathrm{L}$. Afterwards, the concentrations declined until reaching a minimum value of $7 \mathrm{mg} / \mathrm{L}$ (Table 5). P4 presented behavior that is likely related with the presence of preferential flow. Therefore, in $\mathrm{P} 4$, the highest $\mathrm{NO}_{3}^{-}$concentrations were found at the beginning of the period. P2 and P3 presented a similar behavior, but the maximum $\mathrm{NO}_{3}^{-}$concentration was lower. P1 demonstrated a relatively uniform behavior, with average $\mathrm{NO}_{3}^{-}$concentrations of $16-19 \mathrm{mg} / \mathrm{L}$, probably because of the absorption effects of the hydrogel and peat amendments (Fig. 2).

\section{b) Nitrogen mass balance per fertilization period}

The estimated $\mathrm{N}$ mass balances per plot and fertilization period are presented in Table 6. As observed, the greatest $\mathrm{N}$ contributions were due to the application of fertilizers, which represented approximately $75 \%$ of total N inputs to the plots. Nitrogen inputs from irrigation reflect the irrigation level. In 2009, following the construction of the experimental green, irrigation was performed to complement rainfall because, at several points, rainfall was practically null.

Table 4

Concentration of $\mathrm{NO}_{3}^{-}$in the leachate of plots (September 2008-December 2010) (HY: hydrogel, OM: organic matter).

\begin{tabular}{|c|c|c|c|c|}
\hline Plot & Drainage $(\mathrm{mm})$ & Minimum $\mathrm{NO}_{3}^{-}$concentration $(\mathrm{mg} / \mathrm{L})$ & Maximum $\mathrm{NO}_{3}^{-}$concentration $(\mathrm{mg} / \mathrm{L})$ & Average $\mathrm{NO}_{3}^{-}$concentration $(\mathrm{mg} / \mathrm{L})$ \\
\hline $\mathrm{P} 1(\mathrm{HY}+\mathrm{OM})$ & 345.1 & 2.4 & 82.5 & 19.8 \\
\hline $\mathrm{P} 2(\mathrm{OM})$ & 657.3 & 3.3 & 141.3 & 27.5 \\
\hline P3 (HY) & 466.2 & 3.2 & 200.4 & 35.0 \\
\hline P4 (sand) & 653.9 & 2.9 & 385.9 & 39.9 \\
\hline
\end{tabular}




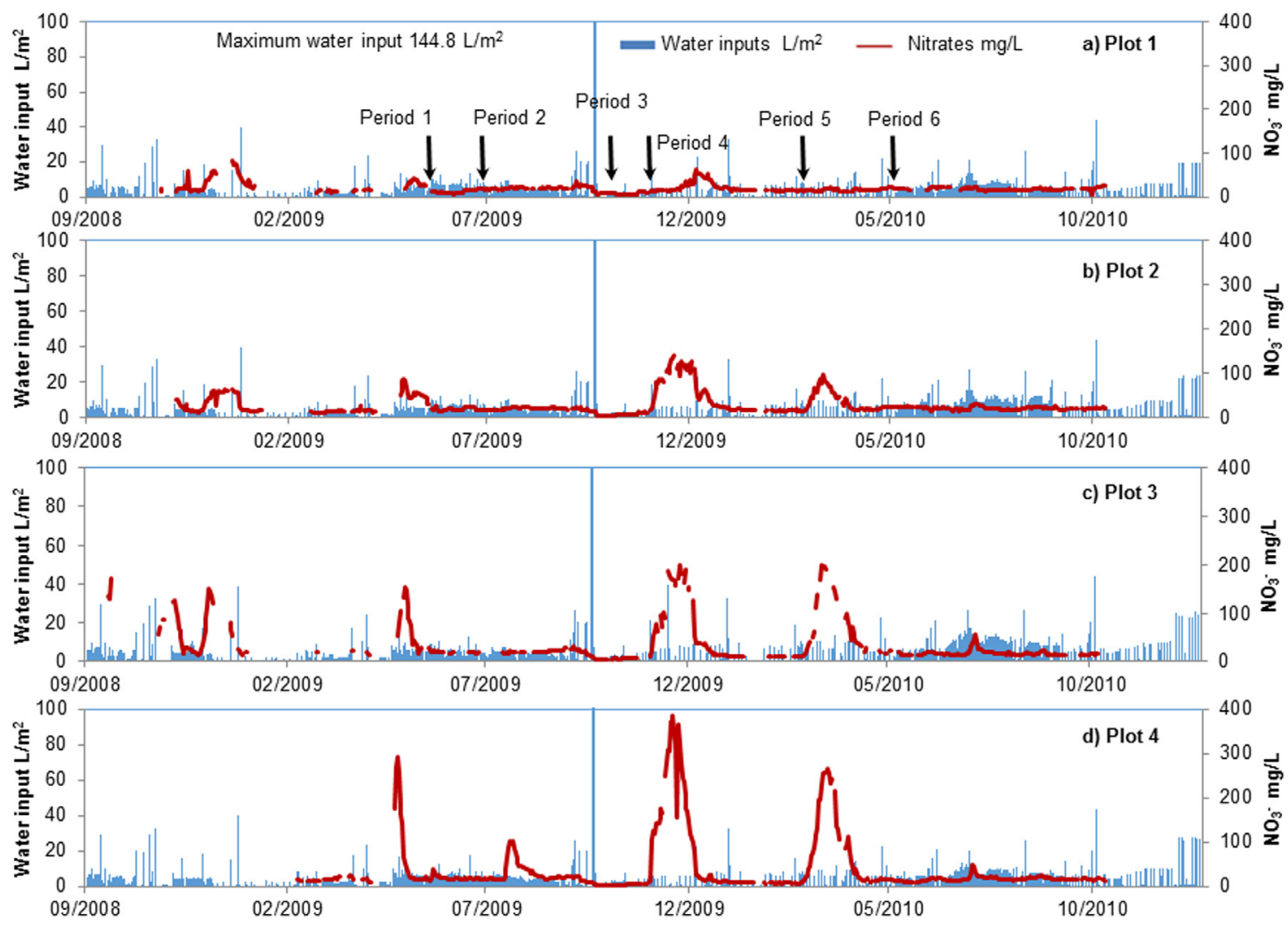

Fig. 2. Water inputs and leached $\mathrm{NO}_{3}^{-}$concentrations in a) $\mathrm{P} 1$, b) P2, c) P3, and d) P4 (arrows indicate fertilization).

The duration of the defined periods was sufficient to document the leaching of excess fertilizer. Overall, the fertilizations were highly efficient, as the percentages of leached N were low. During some periods, leaching barely exceeds $5 \%$ (Table 6 ). In periods 4 and 7 , the percentage of leached $\mathrm{N}$ ranged from 10 to $25 \%$ (with some exceptions); in these latter two periods, leaching can be attributed to excess fertilization with respect to $\mathrm{N}$ demand or to intense irrigation episodes or rainfalls that stimulated water flow, leading to leaching.
Period 1. Small quantities of leached $\mathrm{N}$ were reported in P1 and P3 (Table 6, Fig. 3), demonstrating the influence of the hydrogel amendment. Under these conditions, it may be assumed that any fertilizer dissolved in water is largely available for root absorption. P4 (100\% sand) received the lowest quantity of $\mathrm{N}$ from fertilization $(188.84 \mathrm{~g}$ ) (Table 6). However, the highest amount of total leached N (22.24 g) was also reported in this plot (P4), corresponding with 9\% (Fig. 3), which is likely due to the composition of the plot (100\% sand) and to

Table 5

Fertilization periods and maximum, minimum, and average concentrations of leached $\mathrm{NO}_{3}^{-}$per plot.

\begin{tabular}{|c|c|c|c|c|c|c|c|}
\hline & Start date & End date & Days & Plot & Minimum concentration $(\mathrm{mg} / \mathrm{L})$ & Maximum concentration $(\mathrm{mg} / \mathrm{L})$ & Average concentration $(\mathrm{mg} / \mathrm{L})$ \\
\hline \multirow[t]{4}{*}{ Period 1} & 05/28/2009 & $07 / 21 / 2009$ & 55 & P1 & 7.0 & 18.0 & 11.5 \\
\hline & & & & $\mathrm{P} 2$ & 11.8 & 26.1 & 18.1 \\
\hline & & & & P3 & 17.6 & 23.7 & 10.2 \\
\hline & & & & P4 & 15.7 & 40.9 & 19.1 \\
\hline \multirow[t]{4}{*}{ Period 2} & 07/22/2009 & $10 / 14 / 2009$ & 85 & P1 & 11.7 & 21.8 & 18.5 \\
\hline & & & & P2 & 18.3 & 23.9 & 16.7 \\
\hline & & & & P3 & 3.2 & 39.6 & 15.7 \\
\hline & & & & P4 & 3.3 & 104.3 & 25.8 \\
\hline \multirow[t]{4}{*}{ Period 3} & $10 / 15 / 2009$ & $11 / 09 / 2009$ & 26 & P1 & 5.2 & 12.4 & 7.5 \\
\hline & & & & P2 & 5.2 & 12.3 & 7.8 \\
\hline & & & & P3 & 3.2 & 10.0 & 4.4 \\
\hline & & & & P4 & 2.9 & 8.4 & 4.7 \\
\hline \multirow[t]{4}{*}{ Period 4} & $11 / 10 / 2009$ & 03/03/2010 & 114 & P1 & 12.0 & 61.6 & 19.8 \\
\hline & & & & P2 & 13.3 & 141.3 & 46.4 \\
\hline & & & & P3 & 8.9 & 199.0 & 35.9 \\
\hline & & & & P4 & 6.9 & 385.9 & 67.9 \\
\hline \multirow[t]{4}{*}{ Period 5} & 03/04/2010 & 05/20/2010 & 78 & P1 & 11.3 & 21.9 & 16.3 \\
\hline & & & & P2 & 14.2 & 97.4 & 33.5 \\
\hline & & & & P3 & 8.9 & 200.3 & 41.7 \\
\hline & & & & $\mathrm{P} 4$ & 8.9 & 266.2 & 62.3 \\
\hline \multirow[t]{4}{*}{ Period 6} & $05 / 21 / 2010$ & 07/07/2010 & 48 & P1 & 14.6 & 23.6 & 19.8 \\
\hline & & & & P2 & 12.2 & 27.9 & 19.9 \\
\hline & & & & P3 & 12.2 & 20.6 & 13.9 \\
\hline & & & & P4 & 8.8 & 20.3 & 14.0 \\
\hline
\end{tabular}


Table 6

Nitrogen $(\mathrm{N})$ mass balance per fertilization period and plot.

\begin{tabular}{|c|c|c|c|c|c|c|c|c|c|c|c|c|c|c|}
\hline \multirow[t]{2}{*}{ Period } & \multicolumn{6}{|c|}{ Inputs } & \multicolumn{7}{|l|}{ Outputs } & \multirow{2}{*}{$\begin{array}{l}\% \text { of } \\
\text { drainage } \\
\text { water }\end{array}$} \\
\hline & Plot & $\begin{array}{l}\text { Water } \\
\text { input } \\
(\mathrm{mm})\end{array}$ & $\begin{array}{l}\mathrm{N} \\
\text { fertilization } \\
(\mathrm{g})\end{array}$ & $\begin{array}{l}\mathrm{N} \\
\text { irrigation } \\
(\mathrm{g})\end{array}$ & $\begin{array}{l}\mathrm{N} \\
\text { rainfall } \\
(\mathrm{g})\end{array}$ & $\begin{array}{l}\text { Total N } \\
\text { inputs } \\
(\mathrm{g})\end{array}$ & $\begin{array}{l}\mathrm{N}-\mathrm{NH}_{4} \\
(\mathrm{~g})\end{array}$ & $\begin{array}{l}\% \\
\text { leaching } \\
\mathrm{N}-\mathrm{NH}_{4}\end{array}$ & $\begin{array}{l}\mathrm{N}-\mathrm{NO}_{3} \\
(\mathrm{~g})\end{array}$ & $\begin{array}{l}\% \\
\text { leaching } \\
\mathrm{N}-\mathrm{NO}_{3}\end{array}$ & $\begin{array}{l}\text { Total N } \\
\text { output } \\
(\mathrm{g})\end{array}$ & $\begin{array}{l}\% \\
\text { leaching } \\
\mathrm{N}\end{array}$ & $\begin{array}{l}\text { Water } \\
\text { output } \\
(\mathrm{mm})\end{array}$ & \\
\hline \multirow[t]{4}{*}{1} & P1 & 342.6 & 199.78 & 56.06 & 0.53 & 256.37 & 0.50 & 0.20 & 4.74 & 1.85 & 5.25 & 2.05 & 46.2 & 13.5 \\
\hline & P2 & 318.0 & 200.41 & 54.34 & 0.53 & 255.28 & 0.74 & 0.29 & 11.09 & 4.34 & 11.83 & 4.63 & 73.6 & 23.1 \\
\hline & P3 & 300.2 & 194.70 & 47.60 & 0.52 & 242.80 & 0.29 & 0.12 & 4.64 & 1.91 & 4.93 & 2.03 & 26.9 & 9.0 \\
\hline & P4 & 361.1 & 188.84 & 55.97 & 0.50 & 245.31 & 1.27 & 0.52 & 20.96 & 8.55 & 22.24 & 9.06 & 133.0 & 36.8 \\
\hline \multirow[t]{4}{*}{2} & P1 & 616.0 & 388.48 & 43.30 & 14.28 & 446.06 & 1.45 & 0.33 & 25.42 & 5.70 & 26.87 & 6.02 & 172.0 & 27.9 \\
\hline & P2 & 620.9 & 389.71 & 44.26 & 14.32 & 448.30 & 1.45 & 0.32 & 26.88 & 6.00 & 28.33 & 6.32 & 196.9 & 31.7 \\
\hline & P3 & 603.5 & 378.61 & 40.12 & 13.92 & 432.64 & 1.17 & 0.27 & 22.05 & 5.10 & 23.22 & 5.37 & 185.1 & 30.7 \\
\hline & P4 & 619.2 & 367.21 & 41.43 & 13.50 & 422.14 & 2.16 & 0.51 & 34.51 & 8.18 & 36.67 & 8.69 & 227.3 & 36.7 \\
\hline \multirow[t]{4}{*}{3} & P1 & 59.8 & 70.82 & 9.11 & 0.25 & 80.18 & 0.05 & 0.06 & 0.48 & 0.60 & 0.52 & 0.65 & 7.4 & 12.4 \\
\hline & P2 & 56.3 & 71.04 & 8.53 & 0.25 & 79.82 & 0.08 & 0.10 & 0.97 & 1.22 & 1.05 & 1.32 & 15.6 & 27.7 \\
\hline & P3 & 62.0 & 69.02 & 9.24 & 0.24 & 78.50 & 0.06 & 0.08 & 0.62 & 0.80 & 0.69 & 0.88 & 12.4 & 20.0 \\
\hline & P4 & 58.0 & 66.94 & 8.32 & 0.24 & 75.50 & 0.08 & 0.11 & 0.66 & 0.88 & 0.74 & 0.99 & 17.9 & 30.9 \\
\hline \multirow[t]{4}{*}{4} & $\mathrm{P} 1$ & 308.0 & 271.86 & 22.22 & 7.01 & 301.08 & 0.54 & 0.18 & 18.41 & 6.11 & 18.95 & 6.29 & 89.3 & 29.0 \\
\hline & P2 & 326.0 & 272.72 & 25.35 & 7.03 & 305.10 & 8.57 & 2.82 & 59.08 & 19.36 & 67.65 & 22.17 & 155.2 & 47.6 \\
\hline & P3 & 383.2 & 264.95 & 34.14 & 6.83 & 305.92 & 9.41 & 3.08 & 49.59 & 16.21 & 59.00 & 19.29 & 125.0 & 32.6 \\
\hline & P4 & 317.0 & 256.97 & 22.45 & 6.62 & 286.04 & 45.81 & 16.02 & 84.78 & 29.64 & 130.60 & 45.66 & 142.0 & 44.8 \\
\hline \multirow[t]{4}{*}{5} & P1 & 276.2 & 478.82 & 29.81 & 3.99 & 512.62 & 0.33 & 0.06 & 8.32 & 1.62 & 8.65 & 1.69 & 37.2 & 13.5 \\
\hline & $\mathrm{P} 2$ & 306.0 & 480.34 & 35.00 & 4.01 & 519.34 & 1.91 & 0.37 & 29.65 & 5.71 & 31.56 & 6.08 & 97.3 & 31.8 \\
\hline & P3 & 308.2 & 466.65 & 34.37 & 3.89 & 504.91 & 1.99 & 0.39 & 40.78 & 8.08 & 42.77 & 8.47 & 67.1 & 21.8 \\
\hline & P4 & 302.6 & 452.60 & 32.42 & 3.77 & 488.80 & 2.72 & 0.56 & 54.48 & 11.15 & 57.20 & 11.70 & 90.9 & 30.0 \\
\hline \multirow[t]{4}{*}{6} & $\mathrm{P} 1$ & 283.5 & 19.66 & 40.50 & 1.81 & 61.97 & 0.19 & 0.31 & 4.26 & 6.88 & 4.45 & 7.18 & 23.9 & 8.4 \\
\hline & $\mathrm{P} 2$ & 360.2 & 19.73 & 53.72 & 1.81 & 75.26 & 0.58 & 0.77 & 19.05 & 25.31 & 19.63 & 26.08 & 116.5 & 32.3 \\
\hline & P3 & 372.1 & 19.16 & 54.18 & 1.76 & 75.11 & 0.29 & 0.39 & 6.64 & 8.85 & 6.93 & 9.23 & 51.8 & 13.9 \\
\hline & P4 & 325.3 & 18.59 & 45.02 & 1.71 & 65.31 & 0.28 & 0.43 & 9.99 & 15.30 & 10.27 & 15.72 & 84.1 & 25.9 \\
\hline
\end{tabular}

the uniformity of water flow. In contrast to the amended plots, water is not retained at the surface.

Period 2. The quantity of $\mathrm{N}$ inputted to the plots of the experimental green almost doubled during this period in comparison to period 1 . The $\mathrm{N}$ contribution from rainfall increased notably, indicating greater frequency of rain (approximately $14 \mathrm{~g}$ of $\mathrm{N}$ per plot) (Table 6). P1, P2, and P3 showed uniform behavior in regard to the quantity of leached $\mathrm{N}$, which may be related to the utilized amendments (hydrogel and organic matter) that improve water retention in the first $10-15 \mathrm{~cm}$ of the plot. A higher percentage of leached N was found in P4 (8.69\%) (Fig. 3).

Period 3. The quantity of $\mathrm{N}$ inputted to the plots of the experimental green was low in comparison to previous periods. Fertilization continued to contribute the most N (89\%) (Table 6). The quantity of leached $\mathrm{N}$ was low (Fig. 3), which may be attributed to the short duration of this period or the utilization of $\mathrm{N}$ by plant roots. Despite the low quantities of leached $\mathrm{N}$ and the short duration of this period, P2 and P4 were associated with the highest leaching percentages (Table 6).

Period 4. Compared with previous periods, greater percentages of leached $\mathrm{N}$ were recorded (Table 6 ). This can be attributed to the large

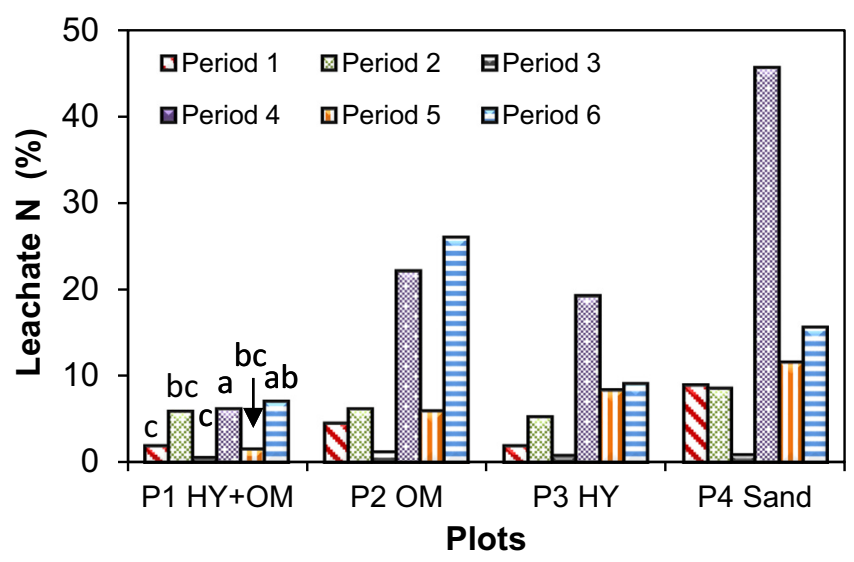

Fig. 3. Percentage of nitrogen $(\mathrm{N})$ leached during the defined study periods. Different letters indicate significant differences between fertilization periods $(P<0.05)$. quantity of inputted $\mathrm{N}$, the duration of the period, and, finally, the low rate of $\mathrm{N}$ absorption by roots that is characteristic of winter. In P1, the percentage of leached $\mathrm{N}$ is $6.29 \%$. Meanwhile, the percentage of leached $\mathrm{N}$ nearly reached $50 \%$ in $\mathrm{P} 4$, even though this plot had the lowest total $\mathrm{N}$ concentration (Table 6, Fig. 3), indicating the leaching of accumulated $\mathrm{N}$.

Period 5. The largest quantity of $\mathrm{N}$ from fertilization was inputted during this period ( $92.4 \%$ on average with respect to total inputs). A minimum and maximum quantity of $452.60 \mathrm{~g}$ and $480.34 \mathrm{~g}$ was applied in P4 and P2, respectively (Table 6).

The lowest amount of leaching was observed in P1 (1.69\%) because of the water retention capacity of the first section as a result of the amendment. The most leaching was observed in P4, despite this plot receiving the lowest amount of $\mathrm{N}$ (Table 6, Fig. 3). This finding coincides with those of the previous study periods and demonstrates the effect of the amendments.

Period 6. The smallest quantity of $\mathrm{N}$ from fertilization was inputted during this period. $a$ and the greatest contribution came from irrigation (Table 6). Large volumes of water were used for irrigation to maintain adequate moisture and to improve the visual quality of grass, as this period corresponded with summer. In particular, $67 \%$ of $N$ was contributed by irrigation, while $29.4 \%$ was contributed by fertilizer and $3.6 \%$ by rainfall.

P1 and P3 exhibited the smallest amount of $\mathrm{N}$ leaching (Fig. 3, Table 6), evidencing the effect of the hydrogel amendment, which retained water circulation and $\mathrm{N}$ dissolved in water. Meanwhile, P2 and P4 exhibited the highest percentages of $\mathrm{N}$ leaching; these percentages are possibly due to low root absorption and water circulation as well as the existence of channels favoring preferential flow.

Based on these data, ANOVA analyses were carried out to establish the degree of similarity of the responses of the planted systems (plots) with respect to $\mathrm{N}$ leaching per fertilization period and plot. Periods 2 and 5 showed similar behavior at a 95\% significance level $(\alpha=$ 0.05 ) and were also similar to periods 1,3 , and 6 to a lesser extent. The same type of fertilizer was used during periods 2 and 5; the largest quantity of $\mathrm{N}$ from fertilization was also applied during these periods (Table 2), corresponding with $103.7 \mathrm{~kg} / \mathrm{ha}$ for period 2 and $127.8 \mathrm{~kg} / \mathrm{ha}$ for period 5 . Meanwhile, periods 1,3 , and 4 significantly differed with respect to the rest of the periods (Fig. 3). The ANOVA 

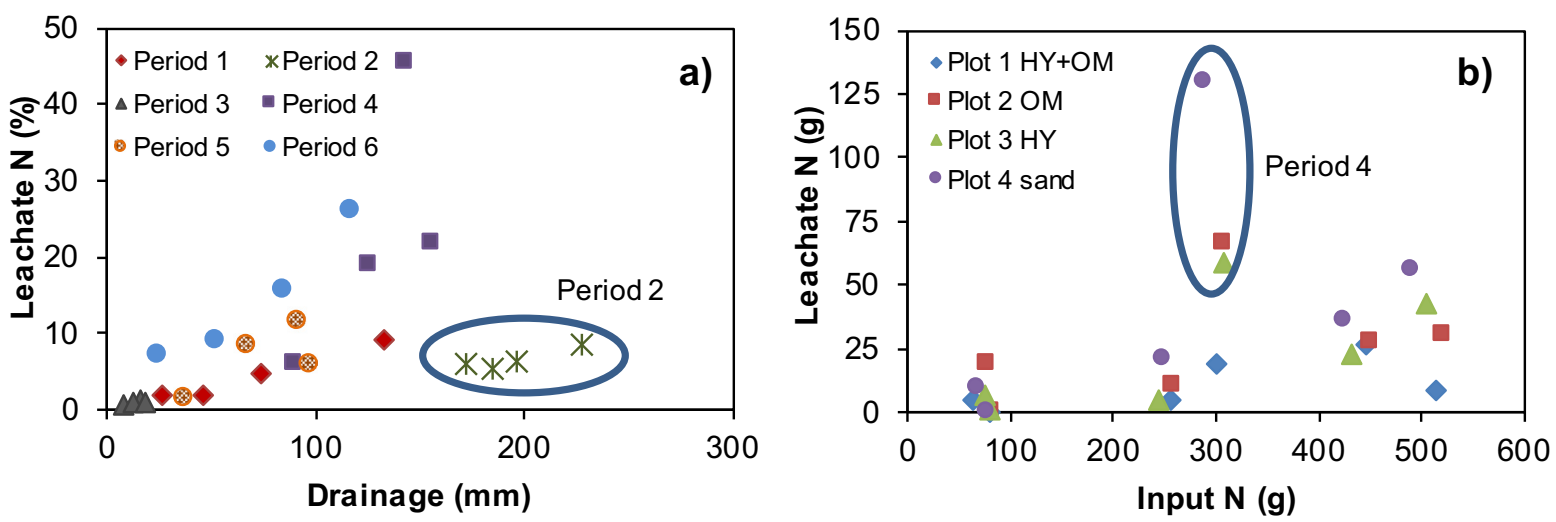

Fig. 4. a) Relationship between water outputs ( $\mathrm{mm}$ ) and leached nitrogen $(\mathrm{N})$ levels $(\%)$ per fertilization period; b) contribution of $\mathrm{N}$ mass ( $\mathrm{g}$ ) vs. leached $\mathrm{N}$ mass ( $\mathrm{g}$ ) in each plot.

analyses indicated that differences in the quantity of leached $\mathrm{N}$ are a function of the fertilizer dose and type utilized each period, except for periods 2 and 5 .

With respect to the plots, no differences in mean values were found at a $95 \%$ significance level $(\alpha=0.05)$, indicating that variance (variability) in the quantity of leached $\mathrm{N}$ was similar in all plots, although total mass of leached $\mathrm{N}$ differed per plot.

To understand the relationship between drainage water volume and $\mathrm{N}$ leaching, the relationship of these two variables was graphed in Fig. 4a. Notably, when drainage volume is greater, the percentage of leached $\mathrm{N}$ also tends to be greater. The points corresponding with period 2 do not show a marked tendency. This may be due to the high volume of input water $(603-620 \mathrm{~mm})$ as well as drainage water (227-172 mm), which may be causing a dilution effect of $\mathrm{N}$, as the greatest volume of drainage water was also found during period 2 .

The relationship between $\mathrm{N}$ contribution and leaching was evaluated. In Fig. 4b, the relationship between these two variables is observed. Some points indicate the presence of an external factor that is likely causing a greater quantity of $\mathrm{N}$ to be leached; for example, during period 4, the quantity of leached $\mathrm{N}$ varied between 59 and $130 \mathrm{~g}$ in P2, $\mathrm{P} 3$, and $\mathrm{P} 4$. The external factor may be the type of applied fertilizer (15-15-15), which was not used in the other periods (Table 2).

These leaching percentages are like those reported by other authors such as Shuman $(2001,2003)$, wherein percentages ranging from 1 to $45 \%$ were estimated for fertilization rates of $12-49 \mathrm{~kg} / \mathrm{ha}$ for substrates equivalent to P2. In the present study, the rate of leaching in P2 ranged from 1 to $26 \%$. Fetter et al. (2012) estimated leaching percentages from 1 to $11 \%$ for fertilization rates of $48-292 \mathrm{~kg} / \mathrm{ha}$ in a silty soil with grass (Lolium perenne L.) where suction cups were installed.

The effects of the fertilization rate and water input on the volume of leached $\mathrm{N}$ were previously confirmed by Barton and Colmer (2006) in a clay soil with grass (Cynodon dacttylon $\mathrm{L}$.). In this study, fertilization rates of 100,200 , and $300 \mathrm{~kg}$ of N/ha were tested. At a high irrigation dose, the percentage of leached $\mathrm{N}$ ranged from 11 to $28 \%$. At a low irrigation dose, the percentage of leached $\mathrm{N}$ was lower than $12 \%$. Also, as it was expected, an increase in the fertilization rate led to an increase in the quantity of leached $\mathrm{N}$. The combined effect of these two factors (higher irrigation and fertilization) resulted in the highest level of $\mathrm{N}$ leaching.
With respect to the effect of peat amendments, the results obtained in the present study are similar to those of Aamlid et al. (2009). These authors carried out a study with lysimeters in an area of $2 \mathrm{~m}^{2}$ simulating a green (sand + Agrostis stolonifera L.) at a fertilization rate of $262 \mathrm{~kg}$ of $\mathrm{N} / \mathrm{ha}$. Nitrogen leaching was lower at lysimeters near areas amended with peat (150.1 $\mathrm{g} \mathrm{NO}_{3}-\mathrm{N} / \mathrm{ha}$ ) than those in areas containing only sand (1390.9 $\mathrm{g} \mathrm{NO}_{3}-\mathrm{N} / \mathrm{ha}$ ).

\subsection{Phosphorus mass balance}

The leaching potential of $\mathrm{P}$ is often considered low because $\mathrm{P}$ can easily form insoluble complexes with aluminum oxides and iron or calcium in the soil (Fetter et al., 2012). However, P leaching can also occur in sandy soils (Elliot et al., 2002; Siddique and Robinson, 2004) and peaty soils whose absorption capacity is very low (Nair and Graetz, 2002).

Overall, throughout the study period (Table 7), a similar behavior of $\mathrm{P}$ was observed in the plots. In contrast to $\mathrm{NO}_{3}^{-}$concentrations, average $\mathrm{PO}_{4}^{-3}$ concentrations in leachates did not exceed $8 \mathrm{mg} / \mathrm{L}$. In this case, leaching is regulated by the low solubility of $\mathrm{P}$ compounds.

As observed in Fig. 5a, in P1, an increase in $\mathrm{PO}_{4}^{-3}$ concentration was mainly favored by two aspects: fertilization and level of water input. However, increased $\mathrm{PO}_{4}^{-3}$ concentrations were also related with the type of flow in the plot. Flow was preferential at the beginning of the period and uniform at the end of the period. Despite these considerations, the maximum $\mathrm{PO}_{4}^{-3}$ concentration did not exceed $20 \mathrm{mg} / \mathrm{L}$ (Table 7).

Phosphate concentrations $>15 \mathrm{mg} / \mathrm{L}$ were recorded in P2, especially at the beginning of the period during planting activities and grass establishment (Fig. 5b). The response of the system to the level of water input can also be observed: Greater water intake was associated with higher $\mathrm{PO}_{4}^{-3}$ concentrations, which may also reflect greater leaching. At the end of the period, $\mathrm{PO}_{4}^{-3}$ concentrations $>25 \mathrm{mg} / \mathrm{L}$ were recorded.

Phosphate concentrations in the leachates of $\mathrm{P} 3$ did not present a uniform behavior; however, similar to P1 and P2, a clear response to water input is observed. After the first year of planting activities, $\mathrm{PO}_{4}^{-3}$ concentrations reduced notably, with average concentrations varying around $5.7 \mathrm{mg} / \mathrm{L}$. This reduction may indicate that the plant cover used a portion of the P, which may have also occurred in the rest of plots.

Table 7

Concentration of $\mathrm{PO}_{4}^{-3}$ in the leachate of plots (September 2008-December 2010) (HY: hydrogel, OM: organic matter)

\begin{tabular}{|c|c|c|c|c|}
\hline Plot & Drainage $(\mathrm{mm})$ & Minimum $\mathrm{PO}_{4}^{-3}$ concentration $(\mathrm{mg} / \mathrm{L})$ & Maximum $\mathrm{PO}_{4}^{-3}$ concentration $(\mathrm{mg} / \mathrm{L})$ & Average $\mathrm{PO}_{4}^{-3}$ concentration $(\mathrm{mg} / \mathrm{L})$ \\
\hline $\mathrm{P} 1(\mathrm{HY}+\mathrm{OM})$ & 345.1 & 0.4 & 16.3 & 5.2 \\
\hline $\mathrm{P} 2(\mathrm{OM})$ & 657.3 & 0.7 & 27.7 & 7.8 \\
\hline P3 (HY) & 466.2 & 0.7 & 23.1 & 5.7 \\
\hline P4 (sand) & 653.9 & 0.5 & 36.7 & 6.9 \\
\hline
\end{tabular}




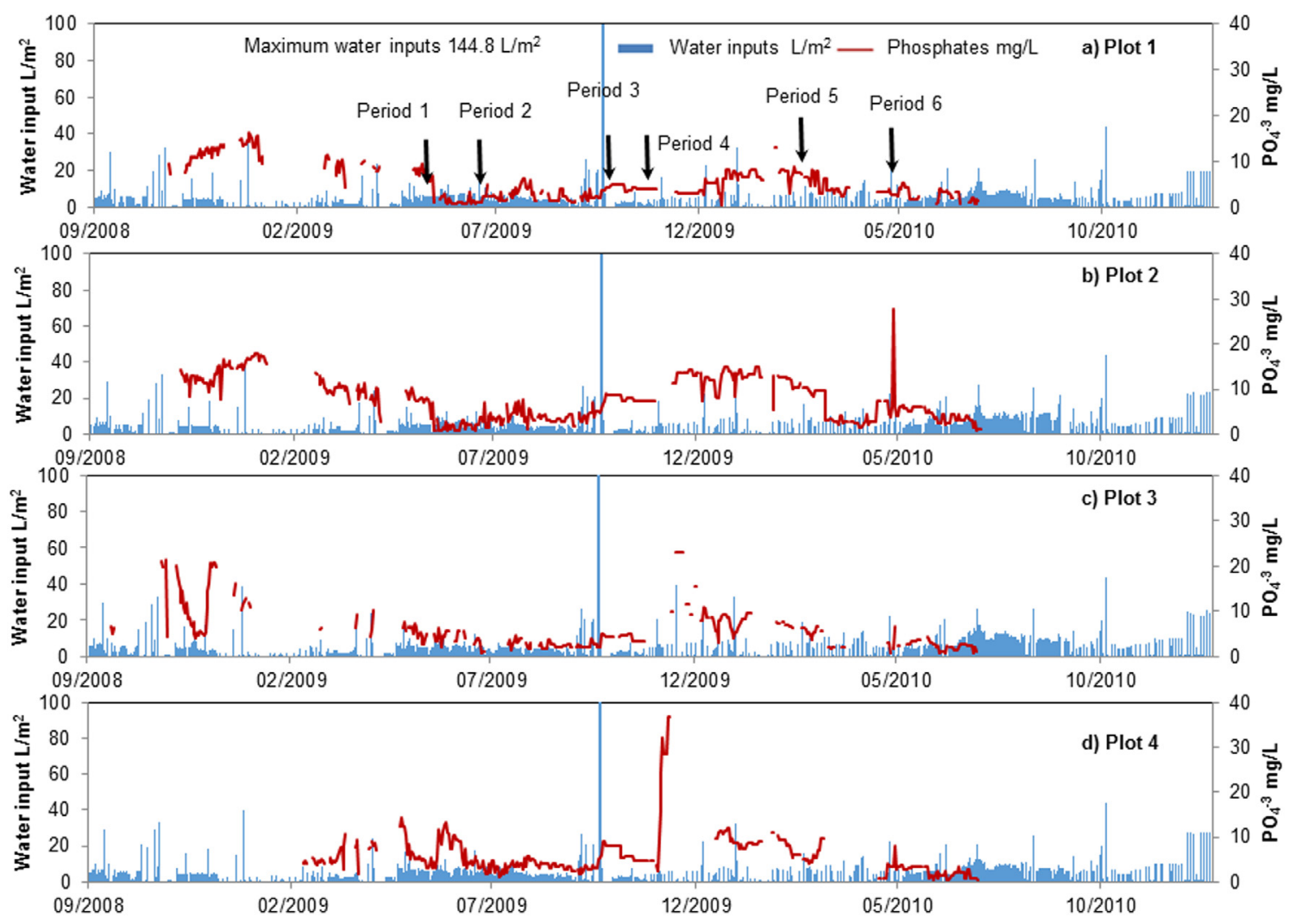

Fig. 5. Water inputs and leached $\mathrm{PO}_{4}^{-3}$ concentrations in a) P1, b) P2, c) P3, and d) P4 (arrows indicate fertilizations).

An average $\mathrm{PO}_{4}^{-3}$ concentration of 6.9 and a maximum concentration of $36.7 \mathrm{mg} / \mathrm{L}$ were found in P4 (Fig. 5d, Table 7), indicating greater leaching in this plot in comparison to the others.

In conclusion, $\mathrm{PO}_{4}^{-3}$ concentrations were low in $\mathrm{P} 1$ and $\mathrm{P} 3$ because of the effect of the amendments, whereas $\mathrm{PO}_{4}^{-3}$ concentrations were higher in P2 and especially in P4, which did not have any amendment (100\% sand).

Similar to $\mathrm{NO}_{3}^{-}$, the level of water input influenced $\mathrm{PO}_{4}^{-3}$ leaching, especially at water inputs $>10 \mathrm{~mm}$ (Fig. 5). Likewise, the presence of amendments affected water circulation. a) Temporal evolution of leached phosphate per fertilization period

In period 1 and 2 , uniform behavior of $\mathrm{PO}_{4}^{-3}$ concentration was observed in P1 and P2, with average values below $5 \mathrm{mg} / \mathrm{L}$, whereas in P3 the concentrations decreased to values below $3 \mathrm{mg} / \mathrm{L}$ (Fig. 5, Table 8). The highest $\mathrm{PO}_{4}^{-3}$ concentrations were recorded in $\mathrm{P} 4$, ranging from 9 to $13 \mathrm{mg} / \mathrm{L}$ (Table 8). At the beginning of these periods, the maximum concentrations can be related with the recent fertilization and the

Table 8

Fertilization periods and maximum, minimum, and average concentrations of leached $\mathrm{PO}_{4}^{-3}$ per plot.

\begin{tabular}{|c|c|c|c|c|c|c|c|}
\hline & Start date & End date & Days & Plot & Minimum concentration (mg/L) & Maximum concentration $(\mathrm{mg} / \mathrm{L})$ & Average concentration $(\mathrm{mg} / \mathrm{L})$ \\
\hline \multirow[t]{4}{*}{ Period 1} & 05/28/2009 & 07/21/2009 & 55 & P1 & 0.6 & 5.1 & 1.6 \\
\hline & & & & $\mathrm{P} 2$ & 0.7 & 7.1 & 2.4 \\
\hline & & & & P3 & 0.9 & 6.5 & 1.9 \\
\hline & & & & P4 & 1.1 & 13.3 & 5.6 \\
\hline \multirow[t]{4}{*}{ Period 2} & $07 / 22 / 2009$ & $10 / 14 / 2009$ & 85 & P1 & 1.1 & 6.3 & 2.9 \\
\hline & & & & P2 & 1.1 & 8.9 & 4.7 \\
\hline & & & & P3 & 1.6 & 5.8 & 2.5 \\
\hline & & & & P4 & 1.8 & 9.0 & 4.4 \\
\hline \multirow[t]{4}{*}{ Period 3} & $10 / 15 / 2009$ & $11 / 09 / 2009$ & 26 & P1 & 3.5 & 4.4 & 3.9 \\
\hline & & & & P2 & 6.9 & 8.1 & 6.9 \\
\hline & & & & P3 & 3.5 & 4.9 & 2.9 \\
\hline & & & & P4 & 3.7 & 5.8 & 4.7 \\
\hline \multirow[t]{4}{*}{ Period 4} & $11 / 10 / 2009$ & 03/03/2010 & 114 & P1 & 0.5 & 13.1 & 4.9 \\
\hline & & & & P2 & 5.4 & 15.0 & 9.9 \\
\hline & & & & P3 & 3.2 & 23.9 & 6.1 \\
\hline & & & & P4 & 4.6 & 36.7 & 6.6 \\
\hline \multirow[t]{4}{*}{ Period 5} & 03/04/2010 & 05/20/2010 & 78 & P1 & 1.7 & 7.8 & 2.9 \\
\hline & & & & P2 & 1.6 & 27.7 & 5.0 \\
\hline & & & & P3 & 0.7 & 6.7 & 1.4 \\
\hline & & & & P4 & 0.7 & 9.5 & 1.9 \\
\hline \multirow[t]{4}{*}{ Period 6} & $05 / 21 / 2010$ & $07 / 07 / 2010$ & 48 & P1 & 0.7 & 4.1 & 1.5 \\
\hline & & & & P2 & 0.7 & 6.1 & 3.9 \\
\hline & & & & P3 & 0.7 & 4.3 & 2.2 \\
\hline & & & & P4 & 0.5 & 3.4 & 1.9 \\
\hline
\end{tabular}


quantity of water inputted to the system, therefore these concentrations are a response indicative of the close relationship between $\mathrm{PO}_{4}^{-3}$ concentration and water flow.

In the third and sixth periods no $\mathrm{P}$ input from fertilization was recorded. Overall, maximum $\mathrm{PO}_{4}^{-3}$ concentrations were around $8 \mathrm{mg} / \mathrm{L}$ in P2 (Fig. 5, Table 8). For all plots leached $\mathrm{PO}_{4}^{-3}$ concentrations were maintained between 0.5 and $8 \mathrm{mg} / \mathrm{L}$ (Table 8 ). An irregular temporal evolution is observed in Fig. 5 for all plots and may be related with the level of water input as well as the existing flow pattern within each plot.

The behavior of the $\mathrm{PO}_{4}^{-3}$ concentrations during periods 4 and 5 was relatively uniform. This indicates null interaction between $\mathrm{PO}_{4}^{-3}$ and the environment and the existence of continuous leaching (Fig. 5).

In period 4, the behavior $\mathrm{PO}_{4}^{-3}$ concentration in $\mathrm{P} 2$ show a clear response to the level of water input $(20 \mathrm{~mm})$; following excessive water input, $\mathrm{PO}_{4}^{-3}$ concentrations values exceeded $15 \mathrm{mg} / \mathrm{L}$ (Fig. 5). Phosphate concentrations were highest in $\mathrm{P} 4(>35 \mathrm{mg} / \mathrm{L}$ ) but decreased to $10 \mathrm{mg} / \mathrm{L}$ at the end of the period 4 (Table 8 ).

In period $5, \mathrm{PO}_{4}^{-3}$ concentrations above $10 \mathrm{mg} / \mathrm{L}$ were not recorded in the plots during the first days. As time passed, the concentrations decreased below $5 \mathrm{mg} / \mathrm{L}$ (Fig. 5) yet increased once again near the end of the period, but without reaching the maximum values observed at the beginning.

\section{b) Phosphorus mass balance per fertilization period}

Notably, P was not detected in rainwater or irrigation water, so P inputs entirely depended on fertilization (Table 9).

Period 1. The use of a hydrogel amendment in P1 and P3 decreased the leached quantity of $\mathrm{P}$ (Table 9 ). In contrast, the largest quantity of $\mathrm{P}$ was leached in $\mathrm{P} 2$ and $\mathrm{P} 4$. The use of peat also appeared to influence $\mathrm{P}$ retention because $\mathrm{P} 1, \mathrm{P} 2$, and $\mathrm{P} 3$ had similar values for leached $\mathrm{P}$, whereas the percentage of leached $\mathrm{P}$ was greater in $\mathrm{P} 4$.

Furthermore, as $\mathrm{P} 4$ received the lowest quantity of fertilizer, it also received the smallest $P$ input. In this plot, 10 times more $P$ was leached than in P1 (plot with the lowest percentage of leachate), probably as a consequence of water flow (uniform flow) and the absence of amendments (Fig. 6). Meanwhile, in the plots with amendment, water was likely retained at the surface.

Period 2. The quantity of inputted $P$ is one-third of that inputted during the previous period. However, the leached quantity is notable
(Table 9, Fig. 6). Greater relative leaching may be due to the availability of $\mathrm{P}$ from the previous fertilization, which was three times greater; therefore, the grass was likely unable to use new inputs. Also, the high water input (and higher drainage) during this period could promote greater leaching of $P$ retained in the soil (Table 9).

Period 3. Phosphorus concentrations did not exceed $1.5 \mathrm{~g}$ (Table 9). A defined source of $P$ did not exist, so the values reported during this period are assumedly due to $\mathrm{P}$ dissolved in water that was retained in the soil by the amendments. The smallest quantity of leached P was observed $(0.38 \mathrm{~g})$ in P1, followed by P3 and P4, with values of 0.64 and $1.09 \mathrm{~g}$, respectively. In P2, which was amended with peat, the highest $P$ concentration $(1.43 \mathrm{~g})$ was reported. One inference is that roots are not using $\mathrm{P}$ and that peat possibly influences $P$ concentration.

Period 4. P1, P2, and P3 received similar quantities of P. However, the percentages of leachates in these plots differed (Table 9), possibly because of the amendments. The largest quantity of $P$ was received by P2 (sand and peat) wherein the largest percentage of leached P was also reported (15.8\%). In addition, $11.59 \mathrm{~g}$, or $10 \%$ of $\mathrm{P}$, was leached in P3, similar to the amount leached in P4 (Fig. 6).

The influence of peat in the concentrations of leached $\mathrm{P}$ is evident upon comparing P2 (containing peat) and P4. Differences in P input are existent yet not significant; therefore, the higher $\mathrm{P}$ concentration in P2 was likely contributed from organic matter.

Period 5. The leachate percentages were low in all plots (below $6 \%$ ), except in P2 wherein the greatest leaching (13.5\%) was observed (Table 9, Fig. 6). This may be related with the leaching of P accumulated and/or retained in the soil and high water inputs.

The effects of the amendments are also easily observed. The quantity of leachate in P1 was influenced by the double amendment; as a result, $\mathrm{P}$ leaching was reduced, similar to the previous periods. In P2, $13.5 \%$ of total P inputs were leached. These data confirm the possible contribution of $\mathrm{P}$ from the peat amendment. In contrast to the other plots, greater quantities of leached P are reported in P2, except for P4, which leached the greatest quantity of P (6\%) with respect to P1 and P3 (Fig. 6). This response in P4 is due to the transit of P leachate through sandy material. Also, in P3, the amendments lead to fluid retention in the first $10 \mathrm{~cm}$ of the substrate.

Period 6. Similar to period 3, no contributions of P were recorded, and $\mathrm{PO}_{4}^{-3}$ concentrations did not exceed $10 \mathrm{mg} / \mathrm{L}$. However, as observed

Table 9

Phosphorus (P) mass balance per fertilization period (NC: no contribution; NI; no input; ND; not detected).

\begin{tabular}{|c|c|c|c|c|c|c|c|c|}
\hline \multirow[t]{2}{*}{ Period } & \multicolumn{4}{|c|}{ Inputs } & \multicolumn{3}{|l|}{ Outputs } & \multirow[t]{2}{*}{$\%$ of drainage water } \\
\hline & Plot & Water inputs (mm) & P fertilization $(\mathrm{g})$ & Total P inputs ( $\mathrm{g}$ ) & Total P outputs (g) & \% P leaching & Water outputs (mm) & \\
\hline \multirow[t]{4}{*}{1} & P1 & 342.6 & 116.14 & 116.14 & 0.92 & 0.79 & 46.2 & 13.5 \\
\hline & P2 & 318.0 & 116.51 & 116.51 & 1.96 & 1.69 & 73.6 & 23.1 \\
\hline & P3 & 300.2 & 113.18 & 113.18 & 1.32 & 1.17 & 26.9 & 9.0 \\
\hline & P4 & 361.1 & 109.78 & 109.78 & 9.67 & 8.81 & 133.0 & 36.8 \\
\hline \multirow[t]{4}{*}{2} & P1 & 616.0 & 35.29 & 35.29 & 7.36 & 20.87 & 172.0 & 27.9 \\
\hline & $\mathrm{P} 2$ & 620.9 & 35.40 & 35.40 & 12.20 & 34.46 & 196.9 & 31.7 \\
\hline & P3 & 603.5 & 34.39 & 34.39 & 5.26 & 15.29 & 185.1 & 30.7 \\
\hline & P4 & 619.2 & 33.35 & 33.35 & 12.00 & 35.97 & 227.3 & 36.7 \\
\hline \multirow[t]{4}{*}{3} & P1 & 59.8 & $\mathrm{NC}$ & $\mathrm{NI}$ & 0.38 & ND & 7.4 & 12.4 \\
\hline & P2 & 56.3 & $\mathrm{NC}$ & NI & 1.43 & ND & 15.6 & 27.7 \\
\hline & P3 & 62.0 & $\mathrm{NC}$ & $\mathrm{NI}$ & 0.64 & ND & 12.4 & 20.0 \\
\hline & P4 & 58.0 & $\mathrm{NC}$ & $\mathrm{NI}$ & 1.09 & ND & 17.9 & 30.9 \\
\hline \multirow[t]{4}{*}{4} & P1 & 308.0 & 118.53 & 118.53 & 5.51 & 4.65 & 89.3 & 29.0 \\
\hline & P2 & 326.0 & 118.91 & 118.91 & 18.79 & 15.80 & 155.2 & 47.6 \\
\hline & P3 & 383.2 & 115.52 & 115.52 & 11.59 & 10.03 & 125.0 & 32.6 \\
\hline & P4 & 317.0 & 112.04 & 112.04 & 13.49 & 12.04 & 142 & 44.8 \\
\hline \multirow[t]{4}{*}{5} & P1 & 276.2 & 43.49 & 43.49 & 2.43 & 5.59 & 37.2 & 13.5 \\
\hline & P2 & 306.0 & 43.63 & 43.63 & 5.91 & 13.55 & 97.3 & 31.8 \\
\hline & P3 & 308.2 & 42.39 & 42.39 & 1.83 & 4.31 & 67.14 & 21.8 \\
\hline & P4 & 302.6 & 41.11 & 41.11 & 2.48 & 6.03 & 90.9 & 30.0 \\
\hline \multirow[t]{4}{*}{6} & P1 & 283.5 & $\mathrm{NC}$ & $\mathrm{NI}$ & 0.81 & ND & 23.9 & 8.4 \\
\hline & P2 & 360.2 & $\mathrm{NC}$ & $\mathrm{NI}$ & 4.81 & ND & 116.5 & 32.3 \\
\hline & P3 & 372.1 & $\mathrm{NC}$ & $\mathrm{NI}$ & 1.42 & ND & 51.8 & 13.9 \\
\hline & P4 & 325.3 & $\mathrm{NC}$ & $\mathrm{NI}$ & 1.63 & ND & 84.1 & 25.9 \\
\hline
\end{tabular}




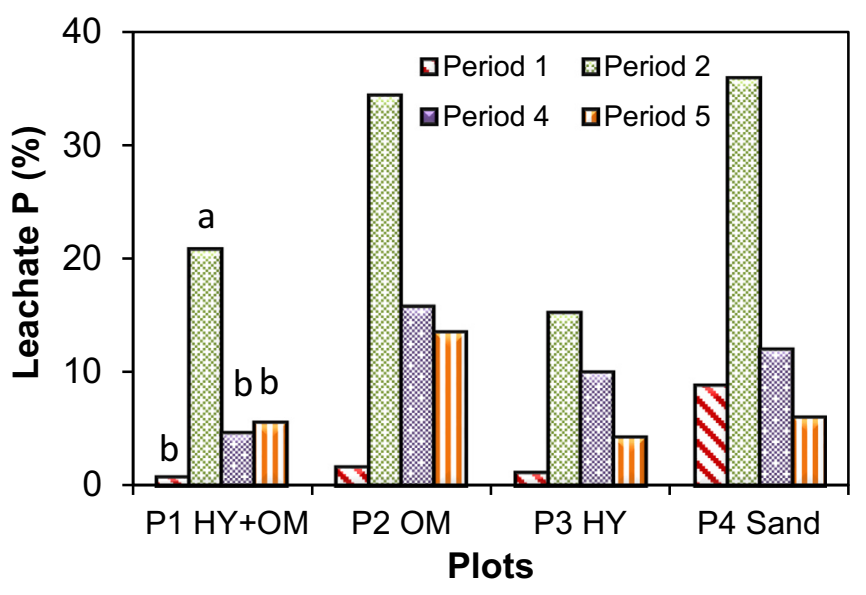

Fig. 6. Percentage of phosphorus $(\mathrm{P})$ leached during the defined study periods. Different letters indicate significant differences between fertilization periods $(P<0.05)$.

in Fig. 6 and Table 9, P was leached, possibly due to P retained in the surface from previous fertilizations or the P contribution of the amendments. Similar to the previous periods, the highest P leaching was reported in P2.

According to these results, the $\mathrm{P}$ concentrations in leachates detected during periods wherein $P$ was not contributed from fertilization could result from the accumulation and retention of fertilizer from previous periods or the contribution of the amendments, mainly peat.

The degree of similarity between the fertilization periods and plots according to the quantity of leachates was evaluated by ANOVAs. With respect to $\mathrm{N}$, some similarity between periods and plots was found, whereas the average amount of leached $P$ significantly differed per fertilization period at a significance level of $95 \%(\alpha=0.05)$. Specifically, period 2 differed with respect to the other periods. During this latter period, the smallest $P$ dose was applied (Table 2), yet the greatest percentage of drainage also occurred, which likely led to the leaching of $\mathrm{P}$ retained in the soil (Table 9). With respect to the plot, the average quantities of leached $\mathrm{P}$ were significantly similar between plots at a significance level of $95 \%$ ( $\alpha=0.05)$, similar to $\mathrm{N}$.

In general, the percentage of $\mathrm{P}$ leaching did not exceed $12 \%$; greater leaching only occurred during period 2 wherein $15 \%$ and $35 \%$ of $P$ was leached. In this latter period, high water inputs caused extensive leaching of $\mathrm{P}$ retained in the soil. As drainage increased, the percentage of leached $\mathrm{P}$ also increased, as shown in Fig. 7a. The extreme values of $\mathrm{P}$ leaching in P2 corresponding with water outputs around $190 \mathrm{~mm}$ can be highlighted (Table 9).

The positive relationship between $\mathrm{P}$ contribution and leached $\mathrm{P}$ is represented in Fig. 7b. However, this relationship is also likely influenced by processes affecting P during its transport through the substrate

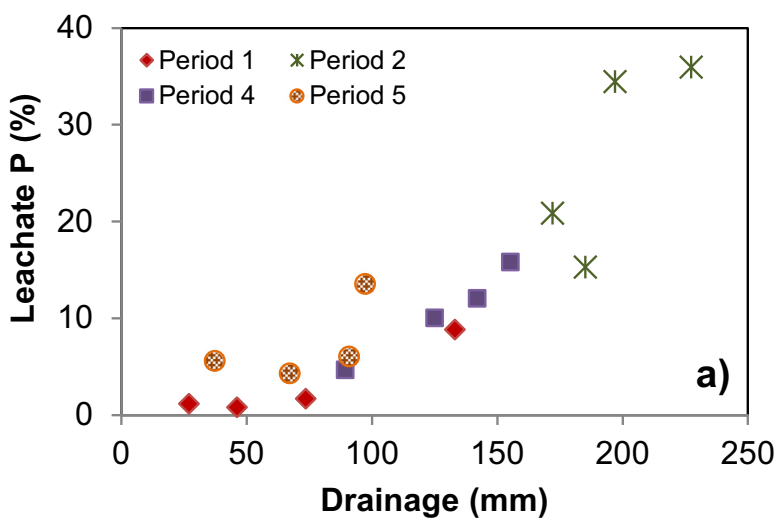

profiles as well as plant absorption (Esteller et al., 2009; Islas-Espinoza et al., 2014).

In two studies of Shuman $(2001,2003)$, a percentage of leached P of $<10 \%$ was found for fertilization rates of $5-11 \mathrm{~kg} \mathrm{P} / \mathrm{ha}$, whereas a leaching percentage between $40 \%$ and $50 \%$ was found for fertilization rates of $11-21 \mathrm{~kg} \mathrm{P} / \mathrm{ha}$. These values are within the same range as those found in period 5, which had a fertilization rate of $11 \mathrm{~kg} \mathrm{P} / \mathrm{ha}$ and leaching percentages of 4-14\%. Meanwhile, Fetter et al. (2012) found $\mathrm{PO}_{4}-\mathrm{P}$ concentrations of $0.1-0.9 \mathrm{mg} / \mathrm{L}$ at fertilization rates of $3.5-283 \mathrm{~kg} \mathrm{P} / \mathrm{ha}$ in a silty soil, indicating minimal leaching as a result of the absorption capacity of the soil.

\section{Conclusions}

a) Nitrogen mass balance

The plots amended with hydrogel (P1 and P3) slowed the water flow and thus maintained higher water content in the first several centimeters of the substrate. This was also reflected in the quantity of leached $\mathrm{N}$ mass contributed from fertilization, irrigation, and rainwater. In these plots, smaller $\mathrm{N}$ losses occurred throughout the evaluated periods, and smaller water volumes were drained. The $\mathrm{NO}_{3}^{-}$concentrations in the leachates of these plots ranged from $19 \mathrm{mg} / \mathrm{L}$ in P1 to $35 \mathrm{mg} / \mathrm{L}$ in P3.

The plot P2 amended with peat and constructed according to the specifications of the USGA presented percentages of $\mathrm{NO}_{3}^{-}$leaching similar to those in P4 (100\% sand). Apparently, the peat amendment did not lead to a significant variation in the quantity of leached $\mathrm{N}$. In this plot, the average $\mathrm{NO}_{3}^{-}$concentration was $27 \mathrm{mg} / \mathrm{L}$.

The plot containing sand (P4) presented the highest percentage of $\mathrm{N}$ loss and drained the highest water volume, reflecting the flow dynamics and hydraulic characteristics of this plot. The average $\mathrm{NO}_{3}^{-}$concentration was $40 \mathrm{mg} / \mathrm{L}$.

Another influential aspect was the irrigation level. High levels of irrigation favor the dissolution and drainage of $\mathrm{N}$. In particular, irrigation levels $>10 \mathrm{~mm}$ and high rainfall levels were associated with greater $\mathrm{N}$ leaching.

b) Phosphorus mass balance

The behavior of $\mathrm{P}$ over the course of the selected periods varied widely in terms of leachate concentration. Similar to N, P leaching was directly influenced by the P mass entering the system.

The effects of hydrogel were evident in P1 and P3. The drainage water volume was lower in these latter plots; accordingly, the $\mathrm{PO}_{4}^{-3}$ concentrations were also lower and tended to be lower than $10 \mathrm{mg} / \mathrm{L}$. Meanwhile, $\mathrm{P} 2$ had a $\mathrm{PO}_{4}^{-3}$ concentration above $15 \mathrm{mg} / \mathrm{L}$; this increase

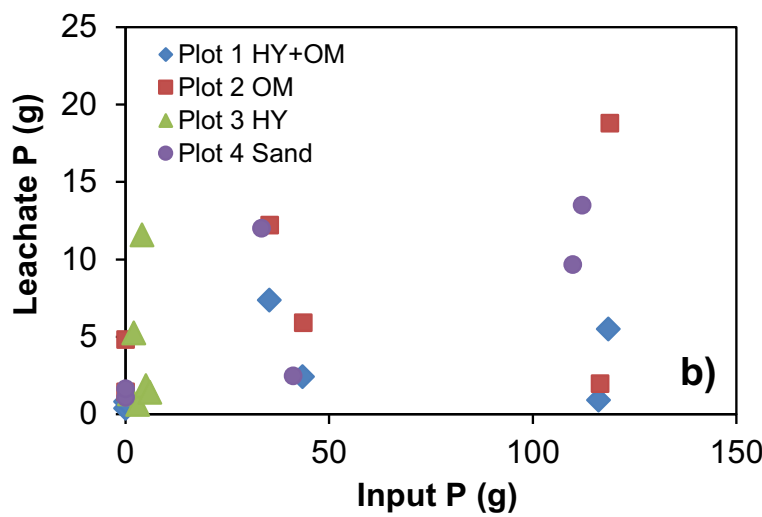

Fig. 7. a) Relationship between water outputs ( $\mathrm{mm}$ ) and leached phosphorus (P) levels (\%) per fertilization period, b) contribution of P mass ( $\mathrm{g}$ ) vs. leached $\mathrm{P}(\mathrm{g})$ mass in each plot. 
can be attributed to the utilized amendment (peat). Finally, in P4, the highest $\mathrm{PO}_{4}^{-3}$ concentrations were present, ranging from 15 to $35 \mathrm{mg} / \mathrm{L}$, as a possible consequence of the scarce interaction of P with the sandy environment.

High water inputs ( $>20 \mathrm{~mm}$ ) resulted in greater fertilizer leaching: this response was observed in all plots. With high water input, P concentrations increased up to $35 \mathrm{mg} / \mathrm{L}$. Water inputs as low as $10 \mathrm{~mm}$, in some cases, were observed to also increase P leaching.

\section{c) Optimal operating conditions of the experimental green}

The actual operating and maintenance conditions of a golf course were evaluated in the experimental green to understand the consequences of distinct irrigation and fertilization practices. Under this scenario, optimal operating conditions can be established. The use of a double amendment (P1) was optimal because it resulted in lower quantities of water and leached $\mathrm{N}$ in comparison to the other plots. Accordingly, the use of a double amendment may lead to a smaller pollutant load and decrease potential groundwater contamination by leachates.

The organic matter (peat) amendment used in P2 also retained water, although this was not notable. Rather, preferential flow seems to have been favored. Therefore, a uniform mixture of peat across the entire plot is recommended.

Another conclusion of the operating conditions, it is that the irrigation levels should be $<10 \mathrm{~mm}$, even if they are more frequent.

In future studies, it is necessary to evaluate the optimal dose of hydrogel that would maximize the moisture content useable by grass and that would reduce $\mathrm{N}$ and $\mathrm{P}$ leaching as well as the volume of percolated water. In addition, it is necessary to establish the efficacy of hydrogel in soil over time.

\section{Acknowledgements}

This project was financed by Campo de Golf del Mediterráneo. Martin del Campo, M.A., expresses his thanks to the National Council of Science and Technology (CONACyT) for the scholarship provided to carry out his doctoral studies and academic stays at the Jaume I University. The authors would like to express gratitude to the Director of the company TerraVida for his recommendations for the use of the TerraCottem®. The authors also wish thanks to anonymous reviewers for their valuable suggestions to strengthen the manuscript.

\section{References}

Aamlid, T.S., Larsbo, M., Jarvis, N., 2009. Effects of surfactant use and peat amendment on leaching of fungicides and nitrate from golf greens. Biologia 64 (3), 419-423. https:// doi.org/10.2478/s11756-009-0094-7.

Abedi-Koupai, J., Sohrab, F., Swarbrick, G., 2008. Evaluation of hydrogel application on soil water retention characteristics. J. Plant Nutr. 31 (2), 317-331. https://doi.org/ 10.1080/01904160701853928.

Akhter, J., Mahmood, K., Malik, K.A., Mardan, A., Ahmad, M., Iqbal, M.M., 2004. Effects of hydrogel amendment on water storage of sandy loam and loam soils and seedling growth of barley, wheat and chickpea. Plant Soil Environ. 50, 463-469. https://doi. org/10.17221/4059-PSE.

Allen, R.G., Pereira, L.S., Raes, D., Smith, M., 1998. Crop Evapotranspiration - Guidelines for Computing Crop Water Requirements - FAO Irrigation and Drainage Paper 56 (ISBN 92-5-104219-5)

Anna, H., Mariola, W., Zbigniew, K., 2011. Effect of hydrogel on the turf grass species growing under salt stress. Ann. Warsaw Univ. Life Sci. SGGW Land Reclamation 43 (1), 47-55. https://doi.org/10.2478/v10060-008-0092-4.

APHA (American Public Health Association), AWWA (American Water Works Association) y WFPC (Water Pollution Control Federation), 2005. Standard Methods for the Examination of Water and Wastewater. 21th edn. APHA, AWWA, WEF, Washington, D.C.

Bai, W., Song, J., Zhang, H., 2013. Repeated water absorbency of super-absorbent polymers in agricultural field applications: a simulation study. Acta Agric. Scand. Sect. B Soil Plant Sci. 63 (5), 433-441. https://doi.org/10.1080/09064710.2013.797488.

Bandenay, G.L., 2013. Caracterización del Flujo Hídrico y La Dinámica Salina en un Green Experimental con Diferentes Sustratos. PhD Dissertation. Universitat Jaume I.Spain.
Barton, L., Colmer, T.D., 2006. Irrigation and fertilizer strategies for minimizing nitrogen leaching from turfgrass. Agric. Water Manag. 80, 160-175. https://doi.org/10.1016/j. agwat.2005.07.011.

Elliot, H.A., O'Connor, G.A., Brinton, S., 2002. Phosphorus leaching from biosolidsamended sandy soils. J. Environ. Qual. 31, 681-689. https://doi.org/10.2134/ jeq2002.6810.

Esteller, M.V., Martínez-Valdés, H., Garrido, S., Uribe, Q., 2009. Nitrate and phosphate leaching in a phaeozen soil treated with biosolids, composted biosolids and inorganic fertilizers. Waste Manag. 29, 1936-1944. https://doi.org/10.1016/j.wasman.2008.12.025.

Fetter, J.C., Brown, R.N., Görres, J.H., Lee, Ch., Amador, J.A., 2012. Nitrate and phosphate leaching under turfgrass fertilized with a squid-based organic fertilizer. Water Air Soil Pollut. 223, 1531-1541. https://doi.org/10.1007/s11270-011-0962-y.

Filipović, V., Toor, G.S., Ondrašek, G., Kodešová, R., 2015. Modeling water flow and nitratenitrogen transport on golf course under turfgrass. J. Soils Sediments 15, 1847-1859. https://doi.org/10.1007/s11368-014-0980-7.

Gaussoin, R., 2012. Peat management on northern golf courses. Minnesota GCSA Mega Seminar. TPC Twin Cities.

Islas-Espinoza, M., Solis-Mejia, L., Esteller, M.V., 2014. Phosphorus release kinetics in a soil amended with biosolids and vermicompost. Environ. Earth Sci. 71, 1441-1451. https://doi.org/10.1007/s12665-013-2549-y.

Johnston, W., Golob, Ch.T., 2002. Nitrogen leaching through a sand-based golf green. USGA. Turfgrass Environ. Res. 1 (19), 1-7 TGIF Record Number: 83193. http:// usgatero.lib.msu.edu/v01/n19.pdf.

Kanji, G.K., 1999. 100 Statistical Tests. SAGE Publications, Oxford.

King, K.W., Balogh, J.C., Agrawal, S.G., Tritabaughc, C.J., Ryan, J.A., 2012. Phosphorus concentration and loading reductions following changes in fertilizer application and formulation on managed turf. J. Environ. Monit. 14, 2929-2938. https://doi.org/10.1039/ C2EM30213F.

Krčmář, D. Marschalko, M., Yilmaz, I., Patschová, A., Chalupková, K., Kovács, T., 2014. Potential pollution risk in natural environment of golf courses: an example from Rusovce (Slovakia). Environ. Earth Sci. 72, 4075-4084. https://doi.org/10.1007/ s12665-014-3296-4.

McAvoy, R.J., 1994. Nitrate nitrogen movement through the soil profile beneath a containerized greenhouse crop irrigate with two leaching fractions and two wetting agent levels. J. Am. Soc. Hortic. Sci. 119 (3), 446-451.

McLeod, M., Aislabie, J., Smith, J., Fraser, R., Roberts, A., Taylor, M., 2001. Viral and chemical movement through contrasting soils. J. Environ. Qual. 30, 2134-2140. https://doi.org/ $10.2134 /$ jeq2001.2134.

Morell, I., 2006. La demanda de agua para los campos de golf. El agua y el medio ambiente. Instituto de Estudios Almerienses. Colección Ciencia y Tecnología. $\mathrm{N}^{\circ} 2$.

Nair, V.D., Graetz, D.A., 2002. Phosphorous saturation in spodosols impacted by manure. J. Environ. Qual. 31, 1279-1285. https://doi.org/10.2134/jeq2002.1279.

Ramos-Campos, E.V., de Oliveira, Jh.L., Fraceto, L.F., Singh, B., 2015. Polysaccharides as safer release systems for agrochemicals. Agron. Sustain. Dev. 35, 47-66. https://doi. org/10.1007/s13593-014-0263-0.

Savi, T., Marin, M., Boldrin, D., Incerti, G., Andri, S., Nardini, A., 2014. Green roofs for a drier world: effects of hydrogel amendment on substrate and plant water status. Sci. Total Environ. 490, 467-476. https://doi.org/10.1016/j.scitotenv.2014.05.020.

Shuman, L.M., 2001. Phosphate and nitrate movement through simulated golf greens. Water Air Soil Pollut. 129, 305-318. https://doi.org/10.1023/A:1010303025998.

Shuman, L.M., 2003. Fertilizer source effects on phosphate and nitrate leaching through simulated golf greens. Environ. Pollut. 125, 413-421. https://doi.org/10.1016/ S0269-7491(03)00081-2.

Shuman, L.M., 2005. Normal and flush irrigation effects on phosphorus leaching from simulated golf greens in the greenhouse. Water Air Soil Pollut. 160, 133-144. https://doi. org/10.1007/s11270-005-4143-8.

Shuman, L.M., 2006. Normal and flush irrigation effects on nitrogen leaching from simulated golf greens in the greenhouse. Commun. Soil Sci. Plant Anal. 37, 605-619. https://doi.org/10.1080/00103620500449484.

Siddique, M.T., Robinson, J.S., 2004. Differences in phosphorus retention and release in soils amended with animal manures and sewage sludge. Soil Sci. Soc. Am. J. 68, 1421-1428. https://doi.org/10.2136/sssaj2004.1421.

Siyal, A.A., Bristowc, K.L., Sîimunekd, J., 2012. Minimizing nitrogen leaching from furrow irrigation through novel fertilizer placement and soil surface management strategies. Agric. Water Manag. 115, 242-251. https://doi.org/10.1016/j.agwat.2012.09.008.

Smith, M., Allen, R.G., Monteith, J.L., Pereira, L.S., Pruitt, W.O., 1992. Report on the Expert Consultation on Procedures for Revision of FAO Guidelines for Prediction of Crop Water Requirements. Land and Water Development Division. United Nations Food and Agriculture Service.

Ullah, F., Othman, M.B.H., Javed, F., Ahmada, Z., Akil, H.Md., 2015. Classification, processing and application of hydrogels: a review. Mater. Sci. Eng. C 57, 414-433. https://doi.org/ 10.1016/j.msec.2015.07.053.

USGA Green Section Staff, 2004. USGA Recommendations for a Method of Putting Construction. United States Golf Association. Golf House, Far Hill NJ https://www.usga. org/content/dam/usga/images/course-care/2004\%20USGA\%20Recommendations\% 20For\%20a\%20Method\%20of\%20Putting\%20Green\%20Cons.pdf.

Wong, J.W.C., Chan, C.W.Y., Cheung, K.C., 1998. Nitrogen and phosphorus leaching from fertilizer applied on golf course: lysimeter study. Water Air Soil Pollut. 107, 335-345. https://doi.org/10.1023/A:1005096122921. 